Medical Research Archives. Volume 5, issue 5. May 2017.

\title{
The Unifying Effects of Maternal-Placental-Fetal Axis Dysregulation on Neurodevelopment Following Infectious and Toxic In Utero Insults
}

\section{Authors \\ Tracylyn R. Yellowhair, $\mathrm{BS}^{1 *}$, Akosua Y. Oppong, $\mathrm{BS}^{2^{*}}$, Jessie R. Maxwell, $\mathrm{MD}^{1}$, Fatu S. Conteh, $\mathrm{MD}^{2}$, Jessie C. Newville, $\mathrm{BS}^{1}$, Danny A. Rogers, MD $\mathrm{PhD}^{1}$, Teresa Easwaran, $\mathrm{MS}^{2}$, Shenandoah Robinson, $\mathrm{MD}^{2}$, and Lauren L. Jantzie, $\mathrm{PhD}^{1 \#}$. \\ Affiliations \\ ${ }^{1}$ Departments of Pediatrics $\&$ Neurosciences, University of New Mexico School of Medicine, Albuquerque, NM 87131. \\ ${ }^{2}$ Division of Pediatric Neurosurgery, Johns Hopkins Children's Hospital, Johns Hopkins University, Baltimore, MD, 21287.}

\#Corresponding Author: Lauren L. Jantzie, PhD Department of Pediatrics MSC10 5590

1 University of New Mexico Albuquerque NM 87131 Phone: 505-925-0778

Fax: 505-272-8826 ljantzie@salud.unm.edu

*These authors contributed equally to this work.

\begin{abstract}
Homeostasis during pregnancy and in the in utero environment is essential for prenatal development. Prenatal maturation is hallmarked by an orchestrated and rigorous developmental program characterized by critical cascades in multiple organ systems. During these critical periods of development, however, potential vulnerability to injury exists throughout pregnancy. Indeed, the developing central nervous system (CNS) is extremely vulnerable to environmental insults throughout the entirety of gestation. These insults can adversely affect the developing brain and spinal cord, and permanently alter the neurodevelopmental trajectory. Specifically, in utero insults and dysregulation of the maternal-placentalfetal axis can change molecular, cellular, structural, and functional development of the CNS, culminating in adverse outcomes and neurological disorders throughout postnatal life. In this review, we will discuss common infectious and toxin-induced in utero insults that have recently garnered attention, including Zika virus, prenatal opioid and alcohol exposure, and chorioamnionitis. The goals are to identify common pathophysiological mechanisms, to emphasize the urgent need for new diagnostic tools, and to promote a broader understanding of the diverse array of neurological outcomes presenting in these children throughout their lifespan. With an increasing number of infants exposed to in utero infections and toxins, and the expanding public health awareness of the consequences of Zika infection, the opioid crisis, alcohol consumption during pregnancy, and the frequency of preterm birth in the United States, familiarity with the underlying mechanisms of each of these insults is paramount to improve the diagnosis and treatment for this exceedingly vulnerable patient population.
\end{abstract}

Keywords: Neurodevelopment, Chorioamnionitis, Prenatal Alcohol Exposure, Zika Virus, Neonatal Abstinence Syndrome, Preterm birth, Central Nervous System, Opioid, Placenta, Pregnancy. 


\section{The Unifying Effects of Maternal-Placental-Fetal Axis Dysregulation on Neurodevelopment Following Infectious and Toxic In Utero Insults}

\section{Introduction}

The development of the central nervous system (CNS) is a diverse and intricate process that begins early in gestation and continues into adulthood (Figure 1).

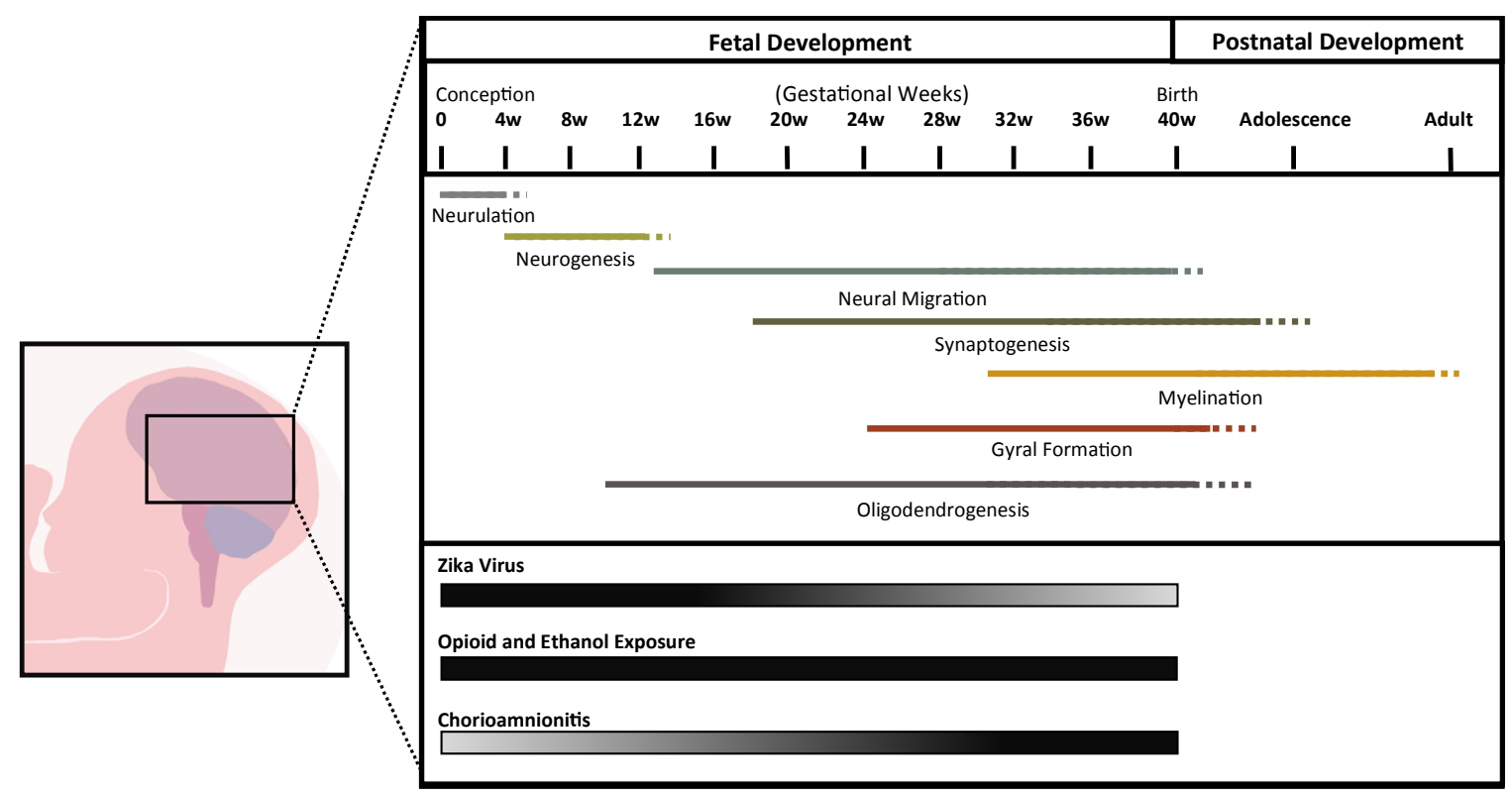

Figure 1. Timeline depicting stages of brain development. Greyscale color map (below) indicates when the fetal brain is most susceptible to prenatal exposure. Resultant complications producing lifelong consequences are not shown. (Adapted from Knuesel I et al., 2014 and Andersen SL., 2003)

Commencing with extensive genesis and proliferation of neural cells in the first trimester of pregnancy, and progressing through maturation, migration and synaptogenesis in the second trimester, diverse neural networks are formed (13). Extending through the third trimester, the fetal brain develops gyri and undergoes extensive myelination and elaborate connectivity that continues to progress after birth. Indeed, dynamic models of neural development highlight the essential interplay of genetic, epigenetic and environmental factors in guiding, shaping and supporting the increasingly complex and elaborate architecture of the growing CNS (2-4).
Considering the highly orchestrated processes of CNS development, the fetal brain and spinal cord are exquisitely sensitive to alterations in the microenvironment during pregnancy, and disruptions in homeostasis can have molecular, cellular, structural and functional implications that are apparent throughout life. This precise and protracted development conveys an inherent and specific risk for the disorders that reflect the timing and the exact developmental processes interrupted by detrimental pathophysiology. Specifically, infections (viral or bacterial) and exposures to toxins (environmental or synthetic) during pregnancy can affect several aspects of prenatal CNS 


\section{The Unifying Effects of Maternal-Placental-Fetal Axis Dysregulation on Neurodevelopment Following Infectious and Toxic In Utero Insults}

development with wide-ranging downstream consequences and lead to structural, functional, and multifaceted neurological deficits, and related comorbidities $(1,2)$.

The placenta plays a key role in maintaining pregnancy, promoting and sustaining fetal growth, and protecting the fetus from foreign substances. It is also an important first line physical and immunological barrier against transmission of infectious and toxic agents during pregnancy (5). Recently, the placenta's unique role as a platform and interface for fetal maturity essential to CNS development has been appreciated in epidemiological, clinical and preclinical studies $(6,7)$. Detailed studies of placental injury can provide a forum for understanding the mechanisms common to fetal systemic inflammation, neuroinflammation and CNS injury (7). Indeed, abnormalities in the placenta double the risk of neonatal encephalopathy (8-12). Minimizing CNS injury commencing in utero hinges on identification of critical pathways underlying the developmental program shared by both the placenta and CNS, such as inflammatory cell migration and recruitment, chemokine and growth factor signaling, and angiogenesis.

While disruptions in placental function directly affect maturation of all organ systems $(13,14)$, the CNS is especially vulnerable, as its complexity and protracted development throughout gestation increases the propensity for injury at some point during pregnancy. Abnormal placental function and injury transmitted through the maternalplacental-fetal axis (Figure 2)

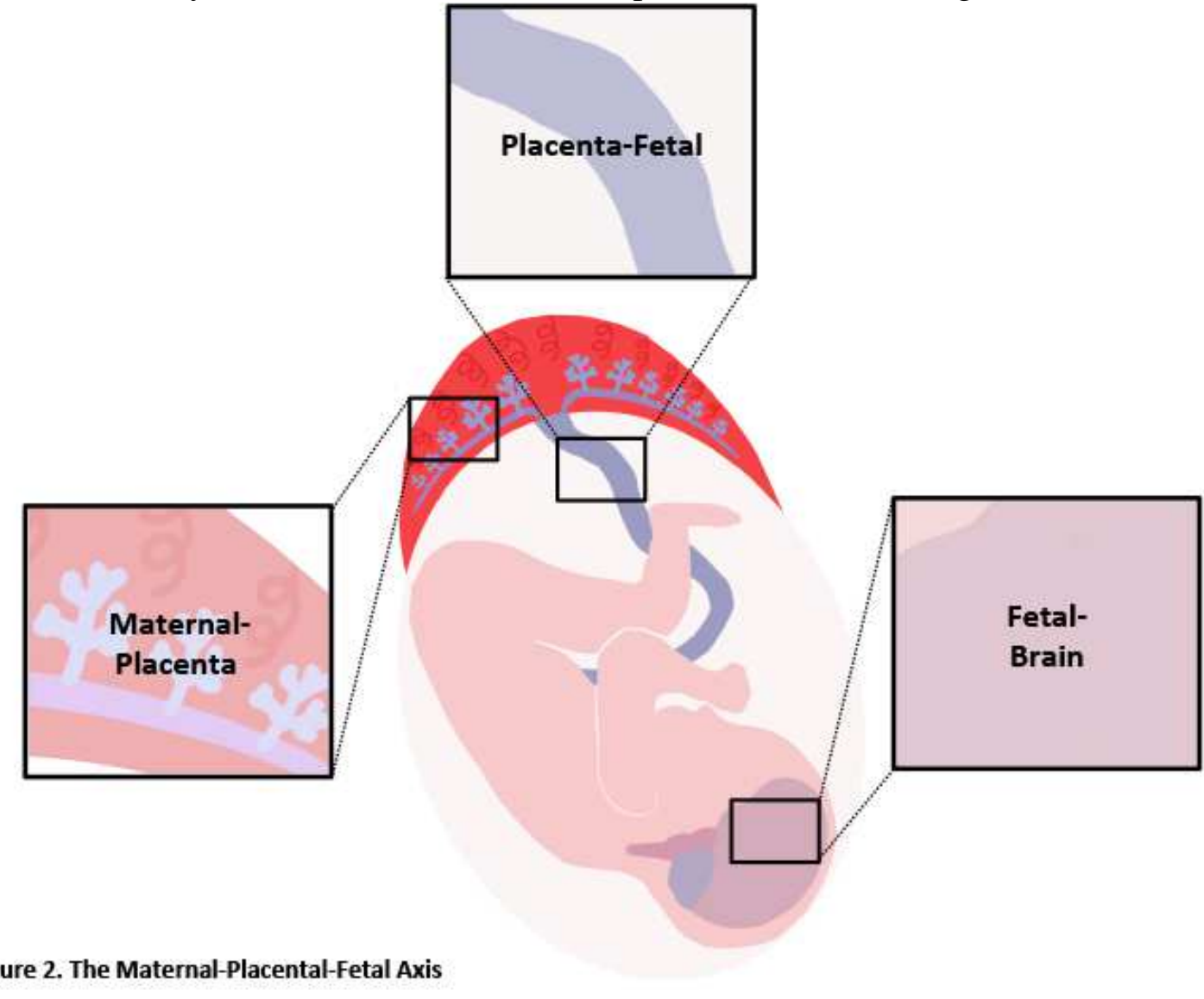

Figure 2. The Maternal-Placental-Fetal Axis 


\section{The Unifying Effects of Maternal-Placental-Fetal Axis Dysregulation on Neurodevelopment Following Infectious and Toxic In Utero Insults}

is detrimental to the developing CNS. Through comprehensive study of this axis, we can begin to dissect the mechanisms common to neurodevelopmental disorders, and identify innovative diagnostic tools and biomarkers of injury and repair. Further, we can develop novel, targeted, and age-appropriate therapeutic strategies, with the goal of stratifying infants to the care and treatment they need when they are born. Here, we will review current literature and focus on four etiologically unique insults that commence in utero and affect the maternal-placental-fetal axis in distinct ways. Individually, these insults represent examples of infection (Zika virus or bacterial chorioamnionitis) and toxins (alcohol and opioids), but each are sentinel injuries that affect the developing CNS.

\section{Zika Virus}

In 2016, the World Health Organization (WHO) declared Zika Virus (ZIKV) a Public Health Emergency of International Concern (PHEIC) based on an extraordinary cluster of neurological disorders and temporal association with ZIKV, with 1.3 million non-congenital cases and 2,160 congenital cases in 20152016 (15-18). Now, despite the WHO lifting its PHEIC warning and emergency designation (19), the neurodevelopmental consequences of ZIKV are only beginning to be understood. Currently, there are 84 countries, territories, or subnational areas with evidence of vector-borne ZIKV transmission $(20,21)$. Thousands of new ZIKV infections continue to be reported throughout Latin America. New countries such as Mexico, Saint Martin, Curaçao and Trinidad and Tobago have reported
CNS malformations and Guillain-Barré syndrome cases associated with ZIKV infection for the first time since February 1, 2017 (20). Like malaria or yellow fever, ZIKV is a continuing regional threat rather than an urgent pandemic, however, the global risk assessment has not changed and ZIKV continues to spread geographically where competent vectors are present (20). As of March 1, 2017, the national arboviral surveillance system (ArboNET) has reported 5,074 cases in the United States (US) and 38,306 cases in US territories (21).

The Aedes mosquito species are chiefly responsible for the transmission of ZIKV, a Flavivirus, to humans and are predominantly found in tropical and subtropical regions $(22,23)$, which explains the high prevalence of ZIKV in countries along the equator. Classified by two transmission cycles, sylvatic (jungle) and suburban-urban, ZIKV is transmitted to humans from other species, and between humans via multiple routes (24). The sylvatic cycle involves viral transmission via blood between nonhuman primates and mosquitos (25). Although this transmission cycle does not lead to direct infection in humans, it creates a large mosquito reservoir that heavily influences suburban-urban transmission. The suburban-urban cycle or human-mosquito-human transmission involves transmission of ZIKV from human to human, mosquito to human, or vice versa (25). The high rates of infection between humans is especially alarming because there are multiple routes of transmission and many infected adults are asymptomatic, which increases the risk of transmission prior to diagnosis $(15,25-$ 
Medical Research Archives. Volume 5, issue 5. May 2017.

\section{The Unifying Effects of Maternal-Placental-Fetal Axis Dysregulation on Neurodevelopment Following Infectious and Toxic In Utero Insults}

33). In addition to mosquito bites, ZIKV can be transmitted through body fluids including saliva, urine, blood products, and semen $(32,33)$.

Based on clinical examinations of microcephalic fetal tissues demonstrating the presence of ZIKV in fetal brains (16, 34-36), and measurable ZIKV in the amniotic fluid of fetuses diagnosed with microcephaly $(28,34,35,37-43)$, the Centers for Disease Control and Prevention (CDC) declared that ZIKV causes microcephaly on April 13, 2016 (21). Shortly thereafter, following a systematic review of the literature up to May 30, 2016, the WHO concluded that ZIKV infection during pregnancy is a cause of brain abnormalities, including microcephaly, and that ZIKV is a trigger of Guillain-Barré syndrome (24). Significantly, both reports acknowledged a primary route of ZIKV infection through vertical transmission, also known as congenital infection, in which the virus is passed in utero from the pregnant woman to the fetus. Transmission in this mode has resulted in a spectrum of neurodevelopmental abnormalities, including lissencephaly, ventriculomegaly, hydrocephalus and severe microcephaly (37, 44-48). Notably, as more infants are born and survive longer, recognition of the notable sequelae of ZIKV is growing. For families with infants found to have congenital ZIKV syndrome, the consequences of ZIKV and spectrum of CNS impairment is only now being appreciated. In addition to microcephaly, many infants have a diverse array of signs and symptoms, collectively named congenital Zika syndrome, including seizures, respiratory insufficiency, dysphagia, muscle weakness, clubbed feet, vision and hearing loss, and cognitive impairment (5,
49). Given the variety of birth defects including CNS malformations, intracranial calcifications, ocular disease, hearing deficits, in combination with intrauterine growth restriction and increased risk of spontaneous abortion, the term congenital zika virus syndrome is used to encompass the broad range pathology and clinical indications of ZIKV infection in the infant $(34,37,49-$ 54). Not surprisingly, the awareness and diagnosis of congenital ZIKV syndrome related sequelae are becoming more apparent and prominent as survivors enter childhood $(37,55,56)$.

\section{Clinical Presentation of Zika Virus}

Nearly $80 \%$ of adults, including pregnant women, infected with ZIKV are asymptomatic (57-60), which makes the clinical diagnosis of ZIKV exceedingly difficult. Symptoms in adults, when present, are similar to other viral illnesses and can include malaise, fever, conjunctivitis, arthralgia, myalgia, fatigue, headache, retro-orbital pain, vomiting and lymphadenopathy (26, 57, 61-63). The criterion for clinical diagnosis is currently based on the compendium of symptomology, and requires the presence of a maculopapular rash with at least two of the following: fever, non-purulent conjunctivitis, polyarthralgia, and periarticular edema $(57,64-66)$.

Together with symptoms and recent history of travel, a diagnosis of ZIKV can only be confirmed through laboratory tests on blood or other body fluids (24). Like other flaviviruses, ZIKV can be detected using reverse-transcriptase polymerase chain reaction (RT-PCR) and serology (67, 68). Specifically, ZIKV can be detected in most body fluids, including saliva, urine, cerebrospinal fluid, serum, tears, semen, breast milk, vaginal and 


\section{The Unifying Effects of Maternal-Placental-Fetal Axis Dysregulation on Neurodevelopment Following Infectious and Toxic In Utero Insults}

cervical mucous, and amniotic fluid (26, 31-33, 69-73), and RT-PCR is best utilized for detection within one week of symptom onset $(25,49,73,74)$. IgMcapture enzyme linked immune-sorbent assay, the only commercially FDAapproved serologic test, can be used to test serum and cerebrospinal fluid after 4 days of symptoms and for up to 12 weeks after infection $(25,49,73,75)$.

In pregnant women who are suspected of ZIKV infection, ultrasonography is used to monitor potential microcephaly and other fetal and placental abnormalities, such as intrauterine growth restriction, anhydramnios and hydrops fetalis $(5,76-$ 80). In the fetal brain, absence of corpus callosum, abnormal gyration, hydranencephaly, ventriculomegaly, brain atrophy, and/or cerebral calcifications can be found $(18,25,28,30,41,47,51,55$, $65,81,82)$. These neurodevelopmental anomalies can be detected as early as 18 to 20 weeks, but typically are not detected until the second and third trimester. A comprehensive review of the birth defects potentially related to ZIKV infection during pregnancy is presented in Honein et al., 2017 (49).

The most profound symptom and hallmark of congenital ZIKV infection is microcephaly $(16,37,47,48,51,52,55$, 83-85). Notably, the severe microcephaly that occurs with congenital ZIKV can often be accompanied by a fetal brain disruption sequence (FBDS), defined by overlapping cranial sutures, prominent occipital bone, craniofacial disproportion, and redundant scalp skin $(54,59,86)$. In the US, microcephaly occurs in only a small subset of infected neonates, approximately $1-13 \%$ of all congenital ZIKV cases $(55,87,88)$. The timing of viral exposure, viral load and gestational age of the fetus contributes to the severity of abnormalities in congenital ZIKV syndrome $(16,50,59)$. Infection during the first trimester of pregnancy is most likely to result in microcephaly and more severe neonatal outcome, because genesis and migration of neurons is occurring rapidly at that time $(1-3,5,26,55,89)$ (Figure 1). Concomitant with microcephaly, craniofacial disproportion and multiple abnormalities occur in major brain structures, such as the corpus callosum and cerebellum, predisposing the infant to multiple neurological impairments (55, 90-92). Postnatal infection of the neonate typically causes mild symptoms, similar to those observed in adults, and reflects the relative maturation of the CNS at term compared to early in gestation $(65,87,88)$.

Clinically, microcephaly is defined as an abnormally small head size, which is measured using the occipitofrontal circumference (OFC). Microcephaly typically is diagnosed when the OFC at birth is less than the $3^{\text {rd }}$ percentile for age, when controlled for sex and gestational age (93). In severe cases of microcephaly, the skull may appear concave with overlapping sutures and abnormal skin folds $(54,86)$. In addition, other structural abnormalities that reflect the developmental timing of infection can be present, and include cortical and subcortical atrophy, hydrocephalus, parenchymal calcifications, polymicrogyria, lissencephaly and ventriculomegaly $(26,34,48,49,54,91$, $94,95)$. The functional manifestations of these multiple structural brain abnormalities include epilepsy, intellectual delay, speech and motor control abnormalities, and vision and hearing loss (49, 96, 97). Importantly, 
Medical Research Archives. Volume 5, issue 5. May 2017.

\section{The Unifying Effects of Maternal-Placental-Fetal Axis Dysregulation on Neurodevelopment Following Infectious and Toxic In Utero Insults}

these symptoms are not always apparent at birth.

\section{Effects of ZIKV on the Maternal- Placental-Fetal axis}

Teratogenic infectious agents that are transmitted from mother to infant during pregnancy, childbirth, or breast-feeding have historically been classified as TORCH pathogens ( $\boldsymbol{T}$ oxoplasmosis, $\boldsymbol{O}$ ther including syphilis, varicella-zoster, parvovirus-B19, human immunodeficiency (HIV), Rubella, Cytomegalovirus (CMV), and Herpes simplex virus (HSV) (91, 98). Neurodevelopmental malformations have previously been linked to many viral infections, including CMV, rubella, West Nile, HIV, HSV, and Chikungunya, and each of these pathogens can cross the placenta $(26,84,99-101)$. Interestingly, the structural brain abnormalities observed from congenital ZIKV infection are most similar to those due to CMV infection $(84,101)$ and ZIKV now joins the list of viral TORCH pathogens $(29,91$, 98). Given the rapid expansion of the CNS during the first trimester, there are multiple putative mechanisms of microcephaly. Conclusive evidence for the precise molecular events leading to congenital ZIKV syndrome remain poorly defined. Dermal fibroblasts and epidermal keratinocytes are the primary targets of ZIKV infection, followed by infection of dermal dendritic cells, which facilitates systemic viral dissemination throughout the body (102). ZIKV transmission can occur through the maternal-placental-fetal axis during pregnancy through the circulation (5). Placental macrophages and cytotrophoblasts are the cell types primarily responsible for transplacental transmission of ZIKV from the pregnant woman to the fetus $(5,45,103-105)$. Viral production in placental macrophages augments production of chemokines and cytokines, culminating in a robust inflammatory reaction $(82,89,102,106-$ 108). In addition to placental cells, ZIKV also infects vascular epithelial cells (45, 103, 109), resulting in cell death and disruption of major vessels in the placental barrier. Cumulatively, these changes create a toxic placental microenvironment defined by excessive hypoxia-ischemia and inflammation that subsequently facilitates CNS injury through limited oxygen and nutrient delivery, and inflammatory-driven neural cell death.

In addition to replicating in placental cells, ZIKV can overwhelm the maternal immune system and the placenta, and ultimately cross the immature blood-brain barrier to allow direct ZIKV uptake by neural cells (109). Once ZIKV enters a cell, it hijacks essential replication and assembly machinery, interfering with proliferation and survival of neural progenitors (26). In contrast to the changes in the transcriptome induced by the Dengue virus, ZIKV has a robust and selective impact on genes involved in DNA replication and repair $(35,110)$. Through specific cell-surface tyrosine kinase receptors such as AXL, and other adhesion molecules, ZIKV can invade developing radial glia, astrocytes, endothelia, microglia, and neural progenitor cells $(35,84,111,112)$. Interestingly, AXL is also expressed on a subset of placental trophoblasts $(55,111$, 112) and may correspond to the high efficiency of ZIKV infection in these cell types. Gene expression and proteomic analyses confirm several ZIKV-induced changes in protein and messenger RNA in infected neural cells, especially those 


\section{The Unifying Effects of Maternal-Placental-Fetal Axis Dysregulation on Neurodevelopment Following Infectious and Toxic In Utero Insults}

essential to proliferation, synapse organization, differentiation, migration, organelle localization, immune response and cell adhesion (89, 106, 109, 113, 114). A neuroinflammatory reaction is also commonly observed, including microglial hyperplasia, astrocytic hypertrophy and macrophage, lymphocyte and leukocyte infiltration $(94,109,115-$ 117). Indeed, this neuroinflammatory activation can drive neural cell pathophysiology through the release of chemokines and cytokines and further immune cell recruitment and activation (26). Similarly, preclinical models demonstrate replication of ZIKV in radial glia and neural progenitors, major hubs of neuronal migration and neurogenesis, and confirm substantial augmentation of apoptosis and autophagy mechanisms of cell death $(35,42,43,81,89,106,114$, $118,119)$. The cumulative impact of the changes that modify proliferation and migration dynamics is a dystrophic brain (109). Overall, these data show CNS injury secondary to ZIKV-induced neural cell injury, plus ZIKV-induced placental insufficiency and inflammation, impairs neurogenesis and neural cell migration. The combination of placental and neural cell injury leads to microcephaly, encephalomalacia, hydrocephalus and additional CNS abnormalities common to congenital ZIKV syndrome (34, 78-80). Currently there is no cure for ZIKV; however, through increased understanding of ZIKV pathophysiology, preventative measures may be formulated and implemented, with treatments developed to aid the numerous infants born with brain injury secondary to congenital infection. Accordingly, current prevention efforts are focused on reducing infections in pregnant women by implementing travel restrictions prior to and during pregnancy, especially in geographical locations with known cases of Zika infection (25). Given the high probability of asymptomatic individuals (26), the CDC currently recommends high risk individuals, such as women who want to get pregnant or are pregnant, be screened and tested for Zika virus regularly (21). Like the CDC, the World Health Organization (WHO) also provides guidelines for preventing ZIKV transmission, and provides a framework for sexually active men and women in order to prevent possible adverse pregnancy and fetal outcomes (24). Specifically, in regions with active transmission of ZIKV, the WHO recommends pregnant women should consistently and correctly use condoms or abstain from sexual activity for at least the duration of the pregnancy (24). In regions with no active transmission of ZIKV, WHO recommends practicing safer sex or abstinence for a period of six months for men and women who are returning from areas of active transmission (24).

\section{Prenatal Opioid Exposure}

Opioid prescription rates have risen dramatically over the past several years, and according to the CDC, in some states, there are as many as $96-143$ prescriptions for opioids per 100 adults per year (120). Similarly, there has been an increase in the number of overdose deaths involving heroin (121), and 188,468 pediatric opioid exposures were reported to US poison control centers from 2000-2015 (122). Consistent with this trend, substance use during pregnancy commonly occurs. Although concern regarding substance use in pregnancy is not new, it has recently increased with the breadth of the US opioid epidemic, including the impact on pregnant women and their infants (123, 124). In 2011, the Substance Abuse Mental Health Services Administration 


\section{The Unifying Effects of Maternal-Placental-Fetal Axis Dysregulation on Neurodevelopment Following Infectious and Toxic In Utero Insults}

reported $1.1 \%$ of pregnant women abused opioids (125), with opioid use in pregnancy increasing from 1.19 to 5.63 per 1000 births from 2000 to 2009 (126). Commonly thought to be exclusively related to heroin, morphine, methadone and buprenorphine use, prenatal opioid exposure often also occurs through the use and abuse of prescription opioids such as oxycodone and codeine $(123,124,127)$. Indeed, several studies emphasize the increasing use of prescription opioids among women of childbearing age and pregnant women (123, 124, 128-130), with $22-30 \%$ of women filling at least one prescription for an opioid analgesic during pregnancy $(129,130)$. A dramatic increase in opioid-substitution programs for the treatment of opioid addiction has also been observed $(127,131)$.

Opioid receptors are located throughout the developing CNS, including in the cerebral cortex, amygdala, caudate, putamen and nucleus accumbens, and through their action on endogenous opioid receptors, act to relieve pain $(132,133)$. During pregnancy, however, opioids rapidly cross the placenta and via the fetal circulation have a direct impact on the developing fetal organ systems including the CNS (134-136). For women with opioid use disorder, the abrupt discontinuation of opioids in pregnancy can result in preterm labor, fetal distress, or fetal demise $(123,127)$. Notably, the incidence of preterm birth among opioiddependent mothers is nearly 3 times the national average for non-opioid-dependent mothers (137, 138), suggestive of placental inflammation and instability. Infants exposed to opioids in utero have increased neuropsychological dysfunction, including impaired executive function and attention (134, 139-142). While studies in adults indicate that opioids can induce structural CNS changes, with substantial changes in circuits related to pain and rewards, current knowledge of CNS changes in children with in utero opioid exposure is based on a few small studies $(134,143,144)$.

\section{Clinical Presentation of Prenatal Opioid Exposure}

As opioid use among pregnant women continues to rise, the rate of infants experiencing opioid withdrawal has similarly increased in the US. This postnatal syndrome, known as neonatal abstinence syndrome (NAS), is a withdrawal syndrome due to drug exposure in utero, and it has grown approximately five-fold in the past decade $(123,124)$. It is estimated that an infant suffering opioid withdrawal is born every 25 minutes $(145,146)$, and NAS occurs in $55-94 \%$ of newborns whose mothers were addicted to or treated with opioids while pregnant $(127,147)$. In 2012, NAS was diagnosed in 21,732 infants in the US, and there is noted increased prevalence globally, including England, Canada and Western Australia (127, 148, 149). However, $80 \%$ of opioid prescriptions worldwide are distributed in the US (122, 150). NAS can result from the use of legitimately prescribed drugs, from the abuse of prescription drugs, or from the use of illegal opioids like heroin. Accordingly, maternal maintenance therapy, which includes treatment for opioid addiction with methadone or buprenorphine, can also result in withdrawal symptoms in the infant after delivery (151).

Owing to the timing of maternal drug use, drug type, and infant metabolism, the presentation of NAS may be delayed (123, 131, 147, 152, 153). Similarly, diagnosis is often difficult due to relatively vague 


\section{The Unifying Effects of Maternal-Placental-Fetal Axis Dysregulation on Neurodevelopment Following Infectious and Toxic In Utero Insults}

symptoms that mimic other neonatal issues, dependent on the gestational age of the infant. A summary of clinical manifestations and other consequences of maternal opioid use is reviewed in McQueen et al (127). While seizures and lethargy are readily apparent to clinicians, irritability, poor feeding and autonomic instability may have more subtle presentations. In term infants, the Finnegan Neonatal Abstinence Scoring System, also known as the modified Neonatal Abstinence Scoring System, may be used to quantify the severity of NAS and guide therapy (147, 154-156). The 21-item scale provides a cumulative score based on signs of neonatal opioid withdrawal $(127,147,156,157)$. If the assessment reveals that a neonate has symptoms consistent with NAS, nonpharmacological interventions such as a calm rooming environment with minimal stimuli and supportive care are first implemented (125, 127, 158). Pharmacologic intervention, such as morphine and methadone, are important components of clinical management when non-pharmacologic care is insufficient to mitigate signs and symptoms of NAS $(127,159)$.

\section{The Effects of Opioids on the Maternal- Placental-Fetal Axis}

The pathophysiology of CNS injury related to prenatal opioid exposure is multifactorial and complex. The multifaceted social and environmental risk factors related to maternal health and prenatal care, in addition to the prenatal opioid exposure, also impact the developmental trajectory of the CNS (134). Opioids readily cross the placenta through passive diffusion because they are typically water soluble and lipophilic, with low molecular weight (160). Notably, as gestational age increases, transmission of opioids across the placenta also increases. This phenomenon is primarily related to the reduced developmental expression of Pglycoprotein (P-gp), a drug efflux transporter that has decreasing levels and activity with increasing gestational age $(125,161)$. This facilitates an increased rate of opioid transfer from the maternal to the fetal circulation $(125,161)$. Indeed, clinical consequences of maternal opioid use in the fetus can lead to notable intrauterine growth restriction, abruption placentae, and preterm labor $(124,127$, $137,161,162)$. Opioids affect placental integrity and function, leading to reduced nutrient and oxygen delivery to the fetus, consistent with stress and injury through the maternal-placental-fetal axis (136, 152). Given the role of the placenta in the metabolism and transfer of opioids to the fetus, it is clear that placental function is also a critical determinant of fetal CNS injury and clinical presentation of opioidrelated symptoms following birth (127, 147, 163).

Clinical outcomes in the newborns and children exposed to opioids in utero, including heroin, reveal low birth weight, small head circumference, and smaller brain volumes $(124,127,134,162,164)$. Specifically, these children have a smaller pallidum and putamen (164). These deep nuclei are critical to the function of frontal-striatal circuits implicated in attention and locomotor activity (164166). Volumes of the basal ganglia, thalamus, and cerebellar white matter are also reduced in children with prenatal opioid exposure (134). Beyond standard structural imaging, diffusion tensor imaging (DTI) studies reveal white matter microstructural abnormalities indicative of impaired connectivity and abnormal cerebral circuit development, including 


\section{The Unifying Effects of Maternal-Placental-Fetal Axis Dysregulation on Neurodevelopment Following Infectious and Toxic In Utero Insults}

reduced fractional anisotropy and increased radial diffusion in deep, central and posterior white matter tracts in infants with opioid exposure (134). Alteration of these white matter tracts place children at risk for cognitive and behavioral difficulties including lower mental developmental index, shorter attention spans, and poor social engagement throughout life (167). These data are consistent with the hypothesis that prenatal opioid exposure has direct neurotoxic and gliotoxic effects (168), and may be especially detrimental to developing neural cells prior to myelination of axons. Additionally, opioid receptors are present on neurons, oligodendroglia and astroglia (169), and opioid receptor activation may directly affect neural cell migration and survival (164). In preclinical studies, opioid exposure results in an increase of apoptosis in human neurons and microglia in vitro (168), as well as reduced dendrite length and branching in cortical neurons concomitant with deficits in learning and memory in rodents $(134,170,171)$. Collectively, these data emphasize the detrimental effects of opioid exposure on CNS structure and function. Pregnant women and children are frequently overlooked in the efforts to prevent opioid exposures, and the incidence of NAS and associated increases in health care costs warrant a consistent and comprehensive approach to mitigating the negative outcomes for affected infants, their mothers, and the health care system (122, 127).

\section{Prenatal Alcohol Exposure}

The global prevalence of alcohol use in pregnancy is estimated to be $9.8 \%$ (172, 173). Like ZIKV and opioid use in pregnancy, prenatal alcohol exposure (PAE) is an expansive public health problem. Despite current CDC recommendations to abstain from alcohol use before and during pregnancy (174), approximately $10-15 \%$ of women in the US report drinking some alcohol during their pregnancy, with 3-5\% confirming heavy drinking throughout all stages of pregnancy $(175,176)$. The impact of PAE is devastating, and is the principle cause of fetal alcohol syndrome (FAS) (177179). FAS in the general population is estimated at 14.6 per 10,000 people, and it is projected that 1 in every 67 women who consume alcohol during pregnancy will deliver a child with FAS (172). Indeed, FAS is a disabling potential outcome of drinking during pregnancy, and is the most severe and visibly identifiable form of fetal alcohol spectrum disorder (FASD) (172, 180-183). Representing a multitude of behavioral and cognitive disorders (174, 180, 184), the American Academy of Pediatrics (AAP) estimates that $2-5 \%$ of first grade students suffer from a combination of deficits associated with FASD $(174,176)$.

Alcohol use during pregnancy is an established risk factor for adverse antenatal outcomes including stillbirth, spontaneous abortion, preterm birth, intrauterine growth restriction and low birth weight (185-188). Together, these insults place infants at risk for microcephaly, epilepsy, cerebral palsy, cognitive deficits and attention deficit disorders (179, 181, 189-192). Although the severity of these deficits associated with PAE are time, dose and exposure dependent (190), other risk factors can escalate the degree of these neurodevelopmental deficits including poor maternal nutrition, genetic polymorphisms, inadequate access to health and prenatal care and the concurrent use of other substances 


\section{The Unifying Effects of Maternal-Placental-Fetal Axis Dysregulation on Neurodevelopment Following Infectious and Toxic In Utero Insults}

including opioids (190). PAE impairs hippocampal-mediated working memory, synaptic plasticity, cerebellar-motor coordination, cortical organization, executive functioning, motor function and social behavior, but also augments attention disorders and neuropsychiatric disorders, all of which become more apparent and debilitating throughout life (192-201).

\section{Clinical Presentation of PAE}

FASD causes a spectrum of clinical abnormalities in the developing infant, and commonly affects the CNS, ocular, craniofacial, cardiovascular and endocrine systems (For Review see Del Campo 2016) (202). Infants born with FASD are commonly classified as small for gestational age $(<10 \%$ tile for age), which is associated with poor neurodevelopmental outcomes compared to infants born with appropriate weight, length and OFC for gestational age (203). Infants with FASD may present with facial dysmorphisms, hallmarked by short palpebral fissures, an elongated mid-face, long and flat philtrum, thin upper vermilion, flattened maxilla, and hypoplasia of the nasal bridge (For Review see Del Campo 2016) (202). PAE interferes with highly sophisticated neurodevelopmental pathways during gestation, which can lead to multiple CNS abnormalities. Notably, development of the face and the brain are intimately connected, as the brain provides the structural, cellular, and molecular input that guides the development of the face (202).

Using standard and advanced imaging techniques, structural and diffusion MRI investigations reveal significant brain injury in multiple regions, including the frontal cortex, corpus callosum, striatum, caudate nucleus, thalamus and cerebellum (191, 192, 194-200). Significantly, the corpus callosum, a major white matter structure essential for interhemispheric communication, has been reported to be disproportionately smaller in alcoholexposed neonates $(195,199,200,204-$ 206). Structural deficits in the corpus callosum may lead to poor cognitive performance, and impaired sensory, motor and higher-order neural communication (204-206), as a result of poor connectivity, dysregulated interhemispheric integration, and impaired processing. Likewise, diffusion imaging studies link abnormal callosal microstructure and structural coherence with impaired myelination, diffuse fiber bundles and poor axonal integrity (204, 207). Significantly, these neuroimaging studies corroborate the first autopsy studies of FAS, including those revealing impaired cell migration, and agenesis or thinning of the corpus callosum (183, 208).

Aggregate effects on neural cell proliferation, migration and connectivity yield a spectrum of PAE-related intellectual, behavioral and cognitive deficits, which become more pronounced during an affected individual's life. At the structural level, the first trimester effects of alcohol toxicity, like ZIKV, manifest as impaired neural tube development and microcephaly. The facial dysmorphology characteristics are often present and include other midline structures, such as the corpus callosum $(202,209)$. Primarily, these sequelae are related to impaired cell migration, neurogenesis, synaptogenesis, and oligodendrogenesis (209). In the second and third trimesters, alcohol perturbs cell proliferation and induces errors in migration, while directly activating the molecular machinery of cell 


\section{The Unifying Effects of Maternal-Placental-Fetal Axis Dysregulation on Neurodevelopment Following Infectious and Toxic In Utero Insults}

death pathways, thereby catalyzing massive amounts of pathological cell death, impaired synaptic plasticity, and oxidative stress, thus resulting in longterm functional and behavioral deficits (209).

\section{Effects of Ethanol on the Maternal- Placental-Fetal Axis}

Alcohol consumed by pregnant women easily diffuses through the maternalplacental-fetal axis, and places fetal CNS development at risk (189, 190, 210). Specifically, placental dysfunction secondary to maternal alcohol consumption, plus augmented and prolonged alcohol exposure to the fetus, are highly damaging to the developing CNS. Alcohol impairs placental growth and increases perfusion pressure, which results in structural changes in the placenta, and reduced blood flow and nutrient transport to the fetus throughout pregnancy $(190,211,212)$. Together with the direct toxicity and teratogenic effects of alcohol, newborns exposed to alcohol in utero have a higher probability of poor neurological outcomes due to significant placental dysfunction, including insufficiency and inflammation (190). Prior to 20 weeks' gestation, alcohol crosses the placenta into the amniotic fluid and directly diffuses into the fetus through the immature fetal dermis (189, 213). After 20 weeks' gestation, the fetus begins absorbing alcohol that has passed into the amniotic fluid via swallowing and intramembranous absorption (189, 213). Consistent with the normal cycling of amniotic fluid, alcohol is recycled such that alcohol is excreted unchanged in fetal urine, and again subject to reuptake (213, 214). Compounding these mechanisms, umbilical vessels are extremely sensitive to alcohol and increased placental resistance (210). This effect of alcohol on the umbilical cord vessels results in vasoconstriction and further impairment of alcohol elimination rates from the fetal compartment (211). Women who drink alcohol during pregnancy also have a 5 to 7-fold increased risk of infection, such as chorioamnionitis (215). The increased risk of chorioamnionitis leads to further increased incidence of preterm birth. Together, these effects compound the direct effect of alcohol toxicity on the developing CNS by facilitating hypoxiaischemia and decreasing oxygen availability to the developing fetus.

While the severity of structural and functional CNS injury associated with fetal alcohol exposure is multifactorial, key cellular and molecular mechanisms contribute to the pathophysiology. Alcohol readily interacts with glutamate and $\gamma$-aminobutyric acid (GABA) receptors $\left(\mathrm{GABA}_{\mathrm{A}} \mathrm{R}\right)$, where it acts as an antagonist and agonist, respectively (209, 216). At $\mathrm{GABA}_{\mathrm{A}} \mathrm{Rs}$, alcohol is a positive allosteric modulator, facilitating GABAergic neurotransmission (216). This receptor-mediated effect has profound impacts on excitatory and inhibitory neurotransmission. In adults, facilitation of GABAergic neurotransmission defines the CNS depression and disinhibition related to alcohol consumption (216). However, given that GABAergic signaling is more prominent in the developing CNS, the resultant environment favors neuronal excitation and neurotoxicity related to developmental timing of potassium chloride co-transporters that direct chloride gradients in neural cells (217220). Alcohol also modulates presynaptic glutamate release (209), which further dysregulates synaptic signaling in the developing CNS (209). Besides these effects on neurotransmitter receptors, alcohol increases free radical production, 


\section{The Unifying Effects of Maternal-Placental-Fetal Axis Dysregulation on Neurodevelopment Following Infectious and Toxic In Utero Insults}

stresses cellular metabolism via increasing acetylaldehyde levels, directly facilitates cell death through mitochondrial injury, caspase activation and DNA fragmentation, and limits production of essential neurotrophic factors (209). Taken together, it is clear that alcohol has multiple detrimental mechanisms of action that creates a cerebral microenvironment toxic to developing neural cells and favoring cell death.

\section{Chorioamnionitis}

Chorioamnionitis (CHORIO), defined as inflammation of the placenta and surrounding membranes and representing a combination of infection plus hypoxiaischemia (HI), has recently been appreciated in a significant number of preterm and term infants with perinatal brain injury, including those with stroke (145, 146, 221-231). CHORIO is the most common abnormality found in placentas from very preterm infants, and is a principle cause of preterm birth $(221,223$, $224,232)$. Preterm birth, or delivery prior to 37 weeks' gestation, is the primary cause of perinatal morbidity and mortality in developed countries and impacts approximately $12 \%$ of all deliveries in the US (233).

Preterm infants are at increased risk for numerous neurological complications including intraventricular hemorrhage, encephalopathy of prematurity, and periventricular leukomalacia (234-236). Among children born at $<28$ weeks estimated gestational age (EGA), 30 to $50 \%$ will have borderline (IQ $<85)$ or severe (IQ<70) cognitive delay (237). Typically, deficits are cumulative and children with cognitive and behavioral problems often have cerebral palsy, impaired learning, vision and hearing loss, epilepsy, and overall poor physical health that contributes to the prematurity-related burden of chronic disease in adulthood (238, 239). Owing to cognitive and behavioral impairments, children have more trouble coping with other deficits and experience difficulty transitioning to adult independence (240). The resultant societal costs are extensive and exceed an estimated annual expense of 26 billion US dollars, an estimate that even then significantly underestimates the special education, neuropsychiatric and medical management required for former preterm infants as they age (241). Indeed, recent recognition that prenatal care and prevention efforts are ineffective in reducing the burden associated with neonatal mortality and morbidity in the US collectively emphasizes the absolute necessity that novel neural repair strategies and pathophysiological mechanisms be identified $(242,243)$.

Specifically, CHORIO affects $40-80 \%$ of very preterm deliveries, and $20-34 \%$ of deliveries at term $(222,244,245)$. In term infants with HI encephalopathy, the presence of CHORIO predicts limited responsiveness to hypothermia treatment (244, 246). Indeed, recent neuroimaging studies of preterm infants with detailed placental histology and neonatal neuroimaging at term equivalent age show histological CHORIO is an independent antenatal risk factor for preterm brain injury (247). Additionally, placental abnormalities are an independent risk factor in the pathogenesis of perinatal stroke $(223,224,248-250)$.

CHORIO is most often caused by infection with Mycoplasma or Ureaplasma species (251, 252). With progression through the maternalplacental interface and into the fetus, CHORIO induces fetal inflammatory 


\section{The Unifying Effects of Maternal-Placental-Fetal Axis Dysregulation on Neurodevelopment Following Infectious and Toxic In Utero Insults}

response syndrome (FIRS) (221, 253). FIRS exacerbates the detrimental effects of CHORIO on long-term neonatal outcome, increasing the risk of neonatal sepsis, intraventricular hemorrhage, bronchopulmonary dysplasia and cerebral palsy through a massive fetal immune reaction with increased cytokine production and immune cell recruitment (221, 254-261). In the absence of other risk factors, the cytokine milieu of CHORIO can facilitate a hypercoaguable state or cause direct thromboembolism to the fetal brain $(260,262)$. Notably, prenatal and postnatal inflammatory pathophysiology predicts severe neurologic sequelae later in life (10-12), with the risk for abnormal neurologic outcome highest for preterm infants with both CHORIO and placental perfusion defects (10-12).

\section{Clinical Presentation of CHORIO}

There are numerous risk factors for development of CHORIO including premature prolonged rupture of the membranes, long duration of labor, nulliparity, Group B Streptococcus (GBS) infection, urinary tract infections (252, 263), prenatal alcohol exposure, and prenatal opioid exposure (215). CHORIO is diagnosed with clinical or histological criteria $(222,227,252,264)$. Maternal fever (temperature greater than $100.4^{\circ} \mathrm{F}$ ), maternal tachycardia $(>100$ beats per minute), fetal tachycardia ( $>160$ beats per minute), uterine fundal tenderness, and purulence or foul odor of amniotic fluid are all symptoms of clinical CHORIO $(252,264)$. The histological diagnosis of CHORIO is made by placental and umbilical cord pathology. It is defined as inflammation of the chorion, amnion and placenta, and robust presence of polymorphonuclear leukocytes (PMNs), amnion basement membrane thickening and chorionic microabscesses (60, 146, 232, 265, 266). Often, CHORIO co-occurs with decidual vasculopathy, villous infarction, and increased perivillous and intervillous fibrin deposition (267). Significantly, CHORIO affects placental permeability and blood flow (267), facilitating $\mathrm{HI}$ and transmission of inflammation to fetuses of all gestational ages (262). With histological signs of CHORIO present in as many as $42 \%$ of placentas from unremarkable pregnancies $(261,262)$, it is paramount that greater understanding of the role of sterile and non-sterile placental inflammation in pregnancy be ascertained.

\section{Effects of CHORIO on the Maternal- Placental-Fetal Axis}

The pathophysiology of CHORIO is hallmarked by inflammation and $\mathrm{HI}$, at the maternal-placental interface that directly impacts the fetal microenvironment (259). Uteroplacental hypoperfusion leads to fetal hypoxia and diminishes fetal nutrition, including impaired removal of metabolic products from circulation (146, 259, 265, 268-272). CHORIO generates substantial inflammation and engenders a placental, fetal systemic, and fetal CNS inflammatory response characterized by a robust and highly dysregulated proinflammatory cytokine and chemokine profile (146, 273-275). Cytokines are soluble immune mediators secreted in response to immunological challenges such as infection, and are essential for normal CNS development and normal labor and delivery (276). The birth process is typically associated with a measured cytokine cascade initiated by inflammatory infiltration of the cervix, fetal membranes, and myometrium, which highlights the homeostatic and physiologic roles of cytokines in normal development $(253,277)$. Despite this, 


\section{The Unifying Effects of Maternal-Placental-Fetal Axis Dysregulation on Neurodevelopment Following Infectious and Toxic In Utero Insults}

aberrant cytokine production with infection that affects the maternal-fetal interface in the context of ascending infection from the lower genital tract to the chorioamnion is a major component of extreme preterm labor $(232,266,278$ 281). Cytokines produced in response to intrauterine infection and inflammation cause damage to the developing CNS (273-275). Notably, clinical data reveal that preterm newborns have extensive and extended elevations in inflammatory proteins throughout the perinatal period and elevations in multiple, distinct functional inflammatory protein classes (282-284). Together, these features are strongly linked to neurologic impairment in these infants later in life (282-284).

CHORIO triggers an inflammatory response in maternal-placental-fetal axis that can result in injury to the fetal brain and impair neurodevelopmental trajectory both before and after birth $(285,286)$. Fetal inflammation initiates a neuroinflammatory response through peptides, cytokines, and bacterial products in circulation that cross the blood-brain barrier $(285,286)$, followed by a controlled innate immune response activation by CNS cells such as microglia and peripheral immune cells including neutrophils and leukocytes. Microglia are the innate immune cells of the brain and their activation enables neuroinflammation and modulates excitotoxicity and free radical injury. Together with direct effects on developing brain circuitry and oligodendrocytes, the primary result is cell death and diffuse encephalopathy involving profound gray and white matter injury (287-290). Indeed, numerous studies confirm decreased microstructure in the corpus callosum, cingulum, internal capsule, external capsule and cerebellum. Together with changes in the thalamus in preterm infants, these abnormalities correlate with poor outcome later in life, especially with respect to cognitive, behavioral, and motor performance $(221,247,258,291$ 296). Like ZIKV, prenatal alcohol exposure, and neonatal abstinence syndrome, the brain injury associated with CHORIO and preterm birth is easily an expansive review topic in its own right, with numerous contributions from multidisciplinary investigative teams around the globe. However, most data overwhelmingly support that injury begins in utero for a significant proportion of preterm infants and emphasize the absolute necessity of methods for detecting fetuses and placentas at risk as a means of reducing brain injury and lifelong impairment in this exceedingly vulnerable patient population.

\section{Conclusion}

As the first point of contact, physicians and other health care providers are in a position to fulfill a crucial role in the primary prevention of brain injury in infants, including fetal alcohol syndrome, neonatal abstinence syndome, Zika virus and chorioamnionitis. Steps must be taken to improve awareness about the incidence of preterm births, alcohol use, prescription prescription opioid abuse and infections during pregnancy within the medical community and the public. For Zika virus, prenatal alcohol and opioid exposure, a critical issue is ensuring that pediatric clinicians are aware of maternal exposure, and thus identify infants who should be tested and provided appropriate followup for neurodevelopmental issues (49). Similarly, it is important that public health measures be increased to educate the public about the effects of toxins and illness before and during pregnancy. Safe and judicious prescribing of opioids are 


\section{The Unifying Effects of Maternal-Placental-Fetal Axis Dysregulation on Neurodevelopment Following Infectious and Toxic In Utero Insults}

encouraged in women of childbearing age, as is recording a thorough and accurate medical history including international travel, recreational drug use such as marijuana and methamphetamine in addition to opioid and alcohol use, and history of medications including selective serotonin reuptake inhibitors and benzodiazepines. While the focus was on opioids and alcohol within the present review, polysubstance use and abuse in pregnant women and the subsequent effect on the fetus cannot be overlooked (297303). Marijuana use is one of the most commonly used drugs in pregnancy and lactation. This is of great concern given the lipophilic nature of cannabis and its metabolites thus allowing for rapid transfer through the maternal-placental fetal axis. Numerous reports of cannabis exposure during critical periods of prenatal development detail increased risks for structural and functional brain injury, including neuropsychiatric, behavioral, and executive function impairment later in life $(297,298,300-$ 302).

Minimizing brain injury in infants hinges on identification of critical pathways underlying the developmental program shared by both the placenta and brain. This information is essential for understanding the fundamental mechanisms of transmission of inflammatory signaling through the placenta and blood-brain barrier and subsequent impact on neural development. Disruptions in placental function directly affect organ maturation, and the CNS is particularly vulnerable because of its protracted development throughout gestation and postnatally. Individual and specific windows of vulnerability are defined by the gestational age in which infectious agents or toxins are most likely to be transmitted to the fetus and have detrimental consequences (5). This conferred vulnerability varies for different agents, and is based on both pathogen and host factors, including a complex interplay between the cellular, molecular and anatomic factors through the maternal-placental-fetal axis, which evolves with gestation (5). Cumulatively, infections and toxins during fetal development have persistent and chronic impact beyond neurogenesis and neural cell development through inflammation.

Limited avenues for early detection and diagnosis are additional challenges facing Zika virus, prenatal alcohol and opioid exposure, and preterm infant patient populations. However, the placenta may be key to early diagnosis, and stratification for emerging therapies, with the establishment of pathophysiology specific biomarkers linked to brain injury. Even if novel therapies are discovered to treat CNS injury and improve neurological outcome, definitive medical diagnoses are difficult early in life, thus reducing timely and appropriate medical and supportive care. Clinicians often rely on the appearance of neurological deficits and delayed developmental milestones as the infant matures to diagnose neurodevelopmental insults, which limits the use of effective interventions prior to irreversible CNS injury in the neonatal period. Indeed, early indicators of adverse events are needed to contribute to the ontogeny of impairment as it unfolds across the development, and more sensitive detection measures and earlier recognition of phenotypes by pediatric and primary care physicians will help ensure appropriate and timely evaluation and follow-up of affected infants. Undoubtedly, more complete, comprehensive, and multi-specialty 


\section{The Unifying Effects of Maternal-Placental-Fetal Axis Dysregulation on Neurodevelopment Following Infectious and Toxic In Utero Insults}

clinical assessment of infants will be needed to fully describe the extent of the brain abnormalities and other adverse outcomes in affected fetuses and infants exposed to alcohol, opioids, viruses and/or bacterial infections. Unquestionably, clinical care that is multidisciplinary, collaborative, compassionate and based on the identified needs of the mother-infant dyad will directly benefit all patients with toxin or infectious agent exposure, together with improved diagnosis and preclinical research uncovering fundamental mechanisms of brain injury to facilitate improved neurodevelopmental outcomes amongst our tiniest and most vulnerable patients.

\section{Acknowledgements}

The authors are grateful to Dr. JD Cooney for helpful discussions of the manuscript. 
Medical Research Archives. Volume 5, issue 5. May 2017.

\section{The Unifying Effects of Maternal-Placental-Fetal Axis Dysregulation on Neurodevelopment Following Infectious and Toxic In Utero Insults}

\section{Literature Cited}

1. Maxwell JR, Yellowhair TR, Oppong AY, Camacho JE, Lowe JR, Jantzie LL, et al. Cognitive development in preterm infants: multi-faceted deficits reflect vulnerability of rigorous neurodevelopmental pathways. Minerva Pediatr. 2017.

2. Knuesel I, Chicha L, Britschgi M, Schobel SA, Bodmer M, Hellings JA, et al. Maternal immune activation and abnormal brain development across CNS disorders. Nat Rev Neurol. 2014;10(11):643-60.

3. Andersen SL. Trajectories of brain development: point of vulnerability or window of opportunity? Neurosci Biobehav Rev. 2003;27(1-2):3-18.

4. Stiles J, Jernigan TL. The basics of brain development. Neuropsychol Rev. 2010;20(4):327-48.

5. Vermillion MS, Lei J, Shabi Y, Baxter VK, Crilly NP, McLane M, et al. Intrauterine Zika virus infection of pregnant immunocompetent mice models transplacental transmission and adverse perinatal outcomes. Nat Commun. 2017;8:14575.

6. Fant ME, Fuentes J, Kong X, Jackman S. The nexus of prematurity, birth defects, and intrauterine growth restriction: a role for plac1-regulated pathways. Front Pediatr. 2014;2:8.

7. Jantzie LL, Robinson S. Preclinical Models of Encephalopathy of Prematurity. Dev Neurosci. 2015;37(45):277-88.

8. Badawi N, Kurinczuk JJ, Keogh JM, Alessandri LM, O'Sullivan F, Burton $\mathrm{PR}$, et al. Intrapartum risk factors for newborn encephalopathy: the Western Australian case-control study. BMJ. 1998;317(7172):1554-8.

9. Fleiss B, Tann CJ, Degos V, Sigaut S, Van Steenwinckel J, Schang AL, et al. Inflammation-induced sensitization of the brain in term infants. Dev Med Child Neurol. 2015;57 Suppl 3:17-28.

10. Trivedi S, Joachim M, McElrath T, Kliman HJ, Allred EN, Fichorova RN, et al. Fetal-placental inflammation, but not adrenal activation, is associated with extreme preterm delivery. Am J Obstet Gynecol. 2012;206(3):236 e1-8.

11. Yanowitz TD, Jordan JA, Gilmour $\mathrm{CH}$, Towbin R, Bowen A, Roberts JM, et al. Hemodynamic disturbances in premature infants born after chorioamnionitis: association with cord blood cytokine concentrations. Pediatr Res. 2002;51(3):310-6.

12. Yanowitz TD, Potter DM, Bowen A, Baker RW, Roberts JM. Variability in cerebral oxygen delivery is reduced in premature neonates exposed to chorioamnionitis. Pediatr Res. 2006;59(2):299-304.

13. Morrison JL, Botting KJ, Dyer JL, Williams SJ, Thornburg KL, McMillen IC. Restriction of placental function alters heart development in the sheep fetus. Am J Physiol Regul Integr Comp Physiol. 2007;293(1):R306-13.

14. Sparrow DB, Boyle SC, Sams RS, Mazuruk B, Zhang L, Moeckel GW, et al. Placental insufficiency associated with loss of Cited1 causes renal medullary dysplasia. J Am Soc Nephrol. 2009;20(4):777-86.

15. Weisblum Y, Oiknine-Djian E, Vorontsov OM, Haimov-Kochman R, Zakay-Rones Z, Meir K, et al. Zika Virus Infects Early- and Midgestation Human Maternal Decidual Tissues, Inducing Distinct Innate Tissue Responses in the 


\section{The Unifying Effects of Maternal-Placental-Fetal Axis Dysregulation on Neurodevelopment Following Infectious and Toxic In Utero Insults}

Maternal-Fetal Interface. J Virol. 2017;91(4).

16. Heymann DL, Hodgson A, Sall AA, Freedman DO, Staples JE, Althabe F, et al. Zika virus and microcephaly: why is this situation a PHEIC? Lancet. 2016;387(10020):719-21.

17. Heukelbach J, Alencar CH, Kelvin AA, de Oliveira WK, Pamplona de Goes Cavalcanti L. Zika virus outbreak in Brazil. J Infect Dev Ctries. 2016;10(2):116-20.

18. Heukelbach J, Werneck GL. Surveillance of Zika virus infection and microcephaly in Brazil. Lancet. 2016;388(10047):846-7.

19. (WHO) WHO. Fifth meeting of the Emergency Committee under the International Health Regulations (2005) regarding microcephaly, other neurological disorders and Zika virus`. 201618 November 2016.

20. (WHO) WHO. Situation Report: Zika Virus, Microcephaly, Guillain-Barré Syndrome. 201710 March 2017.

21. (CDC) CfDCaP. Zika Virus. 2016.

22. Plourde AR, Bloch EM. A Literature Review of Zika Virus. Emerg Infect Dis. 2016;22(7):1185-92.

23. Grard G, Caron M, Mombo IM, Nkoghe D, Mboui Ondo S, Jiolle D, et al. Zika virus in Gabon (Central Africa)-2007: a new threat from Aedes albopictus? PLoS Negl Trop Dis. 2014;8(2):e2681.

24. Organization WH. Zika Virus

.20166 September 2016.

25. Petersen LR, Jamieson DJ, Honein MA. Zika Virus. $N$ Engl $J$ Med. 2016;375(3):294-5.

26. Ming GL, Tang $H$, Song $H$. Advances in Zika Virus Research: Stem Cell Models, Challenges, and Opportunities. Cell Stem Cell. 2016;19(6):690-702.
27. Foy BD, Kobylinski KC, Chilson Foy JL, Blitvich BJ, Travassos da Rosa A, Haddow AD, et al. Probable non-vectorborne transmission of Zika virus, Colorado, USA. Emerg Infect Dis. 2011;17(5):880-2.

28. Calvet GA, Santos FB, Sequeira PC. Zika virus infection: epidemiology, clinical manifestations and diagnosis. Curr Opin Infect Dis. 2016;29(5):459-66.

29. Lazear HM, Diamond MS. Zika Virus: New Clinical Syndromes and Its Emergence in the Western Hemisphere. J Virol. 2016;90(10):4864-75.

30. Besnard M, Eyrolle-Guignot D, Guillemette-Artur P, Lastere S, BostBezeaud F, Marcelis L, et al. Congenital cerebral malformations and dysfunction in fetuses and newborns following the 2013 to 2014 Zika virus epidemic in French Polynesia. Euro Surveill. 2016;21(13).

31. Gourinat AC, O'Connor O, Calvez E, Goarant C, Dupont-Rouzeyrol M. Detection of Zika virus in urine. Emerg Infect Dis. 2015;21(1):84-6.

32. Matheron S, d'Ortenzio E, LeparcGoffart I, Hubert B, de Lamballerie X, Yazdanpanah Y. Long-Lasting Persistence of Zika Virus in Semen. Clin Infect Dis. 2016;63(9):1264.

33. D'Ortenzio E, Matheron S, Yazdanpanah $\mathrm{Y}$, de Lamballerie $\mathrm{X}$, Hubert B, Piorkowski G, et al. Evidence of Sexual Transmission of Zika Virus. N Engl J Med. 2016;374(22):2195-8.

34. Mlakar J, Korva M, Tul N, Popovic M, Poljsak-Prijatelj M, Mraz J, et al. Zika Virus Associated with Microcephaly. N Engl J Med. 2016;374(10):951-8.

35. Qian $X$, Nguyen HN, Jacob F, Song H, Ming GL. Using brain organoids to understand Zika virus-induced microcephaly. Development. 2017;144(6):952-7. 


\section{The Unifying Effects of Maternal-Placental-Fetal Axis Dysregulation on Neurodevelopment Following Infectious and Toxic In Utero Insults}

36. Ventura CV, Maia M, Bravo-Filho $\mathrm{V}$, Gois AL, Belfort R, Jr. Zika virus in Brazil and macular atrophy in a child with microcephaly.

Lancet. 2016;387(10015):228.

37. Cauchemez S, Besnard $\mathrm{M}$, Bompard P, Dub T, Guillemette-Artur P, Eyrolle-Guignot D, et al. Association between Zika virus and microcephaly in French Polynesia, 2013-15: a retrospective study. Lancet. 2016;387(10033):2125-32.

38. Calvet G, Aguiar RS, Melo AS, Sampaio SA, de Filippis I, Fabri A, et al. Detection and sequencing of Zika virus from amniotic fluid of fetuses with microcephaly in Brazil: a case study. Lancet Infect Dis. 2016;16(6):653-60.

39. Sadovsky Y, Clifton VL, Knofler M. Editorial: ZIKA virus and placenta. Placenta. 2016;40:A1.

40. Butler D. First Zika-linked birth defects detected in Colombia. Nature. 2016;531(7593):153.

41. Carteaux G, Maquart M, Bedet A, Contou D, Brugieres P, Fourati S, et al. Zika Virus Associated with Meningoencephalitis. N Engl J Med. 2016;374(16):1595-6.

42. Cugola FR, Fernandes IR, Russo FB, Freitas BC, Dias JL, Guimaraes KP, et al. The Brazilian Zika virus strain causes birth defects in experimental models. Nature. 2016;534(7606):267-71.

43. Dang J, Tiwari SK, Lichinchi G, Qin Y, Patil VS, Eroshkin AM, et al. Zika Virus Depletes Neural Progenitors in Human Cerebral Organoids through Activation of the Innate Immune Receptor TLR3. Cell Stem Cell. 2016;19(2):258-65. 44. Rasmussen SA, Jamieson DJ, Honein MA, Petersen LR. Zika Virus and Birth Defects--Reviewing the Evidence for Causality. N Engl J Med. 2016;374(20):1981-7.
45. Quicke KM, Bowen JR, Johnson EL, McDonald CE, Ma H, O'Neal JT, et al. Zika Virus Infects Human Placental Macrophages. Cell Host Microbe. 2016;20(1):83-90.

46. Russo FB, Beltrao-Braga PC. The impact of Zika virus in the brain. Biochem Biophys Res Commun. 2017.

47. Cavalheiro S, Lopez A, Serra S, Da Cunha A, da Costa MD, Moron A, et al. Microcephaly and Zika virus: neonatal neuroradiological aspects. Childs Nerv Syst. 2016;32(6): 1057-60.

48. Moron AF, Cavalheiro S, Milani $\mathrm{H}$, Sarmento S, Tanuri C, de Souza FF, et al. Microcephaly associated with maternal Zika virus infection. BJOG. 2016;123(8):1265-9.

49. Honein MA, Dawson AL, Petersen EE, Jones AM, Lee EH, Yazdy MM, et al. Birth Defects Among Fetuses and Infants of US Women With Evidence of Possible Zika Virus Infection During Pregnancy. JAMA. 2017;317(1):59-68.

50. Millichap JG. Zika Virus Infection and Microcephaly. Pediatr Neurol Briefs. 2016;30(1):8.

51. Barton MA, Salvadori MI. Zika virus and microcephaly. CMAJ. 2016;188(7):E118-9.

52. Rodrigues LC. Microcephaly and Zika virus infection. Lancet. 2016;387(10033):2070-2.

53. Miranda DD, Martelli CMT, Ximenes RAD, Araujo TVB, Rocha MAW, Ramos RCF, et al. Initial Description of the Presumed Congenital Zika Syndrome. American Journal of Public Health. 2016;106(4):598-600.

54. Moore CA, Staples JE, Dobyns WB, Pessoa A, Ventura CV, Fonseca EB, et al. Characterizing the Pattern of Anomalies in Congenital Zika Syndrome for Pediatric Clinicians. JAMA Pediatr. 2017;171(3):288-95. 


\section{The Unifying Effects of Maternal-Placental-Fetal Axis Dysregulation on Neurodevelopment Following Infectious and Toxic In Utero Insults}

55. Johansson MA, Mier-y-TeranRomero L, Reefhuis J, Gilboa SM, Hills SL. Zika and the Risk of Microcephaly. N Engl J Med. 2016;375(1):1-4.

56. Trevathan E. Editorial brain malformation surveillance in the Zika era. Birth Defects Res A Clin Mol Teratol. 2016;106(11):869-74.

57. Duffy MR, Chen TH, Hancock WT, Powers AM, Kool JL, Lanciotti RS, et al. Zika virus outbreak on Yap Island, Federated States of Micronesia. N Engl J Med. 2009;360(24):2536-43.

58. Ioos S, Mallet HP, Leparc Goffart I, Gauthier V, Cardoso T, Herida M. Current Zika virus epidemiology and recent epidemics. Med Mal Infect. 2014;44(7):302-7.

59. Melo AS, Aguiar RS, Amorim MM, Arruda MB, Melo FO, Ribeiro ST, et al. Congenital Zika Virus Infection: Beyond Neonatal Microcephaly. JAMA Neurol. 2016;73(12):1407-16.

60. Oliveira DB, Almeida FJ, Durigon EL, Mendes EA, Braconi CT, Marchetti I, et al. Prolonged Shedding of Zika Virus Associated with Congenital Infection. N Engl J Med. 2016;375(12):1202-4.

61. Araujo LM, Ferreira ML, Nascimento OJ. Guillain-Barre syndrome associated with the Zika virus outbreak in Brazil. Arq Neuropsiquiatr. 2016;74(3):253-5.

62. Parra B, Lizarazo J, JimenezArango JA, Zea-Vera AF, GonzalezManrique G, Vargas J, et al. GuillainBarre Syndrome Associated with Zika Virus Infection in Colombia. N Engl $\mathrm{J}$ Med. 2016;375(16):1513-23.

63. Cao-Lormeau VM, Blake A, Mons S, Lastere S, Roche C, Vanhomwegen J, et al. Guillain-Barre Syndrome outbreak associated with Zika virus infection in French Polynesia: a case-control study. Lancet. 2016;387(10027):1531-9.
64. Campos GS, Bandeira AC, Sardi SI. Zika Virus Outbreak, Bahia, Brazil. Emerg Infect Dis. 2015;21(10):1885-6.

65. de Carvalho NS, de Carvalho BF, Doris B, Silverio Biscaia E, Arias Fugaca C, de Noronha L. Zika virus and pregnancy: An overview. Am J Reprod Immunol. 2017;77(2).

66. Zanluca C, Dos Santos CN. Zika virus - an overview. Microbes Infect. 2016;18(5):295-301.

67. Lanciotti RS, Kosoy OL, Laven JJ, Velez JO, Lambert AJ, Johnson AJ, et al. Genetic and serologic properties of Zika virus associated with an epidemic, Yap State, Micronesia, 2007. Emerg Infect Dis. 2008;14(8):1232-9.

68. Marano G, Pupella S, Vaglio S, Liumbruno GM, Grazzini G. Zika virus and the never-ending story of emerging pathogens and transfusion medicine. Blood Transfus. 2016;14(2):95-100.

69. Barzon L, Pacenti M, Berto A, Sinigaglia A, Franchin E, Lavezzo E, et al. Isolation of infectious Zika virus from saliva and prolonged viral RNA shedding in a traveller returning from the Dominican Republic to Italy, January 2016. Euro Surveill. 2016;21(10):30159.

70. Mansuy JM, Dutertre M, Mengelle C, Fourcade C, Marchou B, Delobel P, et al. Zika virus: high infectious viral load in semen, a new sexually transmitted pathogen? Lancet Infect Dis. 2016;16(4):405.

71. Mansuy JM, Suberbielle E, Chapuy-Regaud S, Mengelle C, Bujan L, Marchou B, et al. Zika virus in semen and spermatozoa. Lancet Infect Dis. 2016;16(10):1106-7.

72. Miner JJ, Sene A, Richner JM, Smith AM, Santeford A, Ban N, et al. Zika Virus Infection in Mice Causes Panuveitis with Shedding of Virus in Tears. Cell Rep. 2016;16(12):3208-18. 


\section{The Unifying Effects of Maternal-Placental-Fetal Axis Dysregulation on Neurodevelopment Following Infectious and Toxic In Utero Insults}

73. Eppes C, Rac M, Dunn J, Versalovic J, Murray KO, Suter MA, et al. Testing for Zika virus infection in pregnancy: key concepts to deal with an emerging epidemic. Am J Obstet Gynecol. 2017;216(3):209-25.

74. Meaney-Delman D, Oduyebo T, Polen KN, White JL, Bingham AM, Slavinski SA, et al. Prolonged Detection of Zika Virus RNA in Pregnant Women. Obstet Gynecol. 2016;128(4):724-30.

75. Lanciotti RS, Kosoy OL, Laven JJ, Panella AJ, Velez JO, Lambert AJ, et al. Chikungunya virus in US travelers returning from India, 2006. Emerg Infect Dis. 2007;13(5):764-7.

76. Franca GV, Schuler-Faccini L, Oliveira WK, Henriques CM, Carmo EH, Pedi VD, et al. Congenital Zika virus syndrome in Brazil: a case series of the first 1501 livebirths with complete investigation. Lancet. 2016;388(10047):891-7.

77. Ritter JM, Martines RB, Zaki SR. Zika Virus: Pathology From the Pandemic. Arch Pathol Lab Med. 2017;141(1):49-59.

78. Martines RB, Bhatnagar J, de Oliveira Ramos AM, Davi HP, Iglezias SD, Kanamura CT, et al. Pathology of congenital Zika syndrome in Brazil: a case series. Lancet. 2016;388(10047):898904.

79. Martines RB, Bhatnagar J, Keating MK, Silva-Flannery L, Muehlenbachs A, Gary J, et al. Notes from the Field: Evidence of Zika Virus Infection in Brain and Placental Tissues from Two Congenitally Infected Newborns and Two Fetal Losses--Brazil, 2015. MMWR Morb Mortal Wkly Rep. 2016;65(6):159-60.

80. Sarno M, Sacramento GA, Khouri R, do Rosario MS, Costa F, Archanjo G, et al. Zika Virus Infection and Stillbirths: A Case of Hydrops Fetalis,
Hydranencephaly and Fetal Demise. PLoS Negl Trop Dis. 2016;10(2):e0004517.

81. Blazquez AB, Saiz JC. Neurological manifestations of Zika virus infection. World J Virol. 2016;5(4):13543.

82. Olagnier D, Muscolini M, Coyne CB, Diamond MS, Hiscott J. Mechanisms of Zika Virus Infection and Neuropathogenesis. DNA Cell Biol. 2016;35(8):367-72.

83. Alvarado MG, Schwartz DA. Zika Virus Infection in Pregnancy, Microcephaly, and Maternal and Fetal Health: What We Think, What We Know, and What We Think We Know. Arch Pathol Lab Med. 2017;141(1):26-32.

84. Faizan MI, Abdullah M, Ali S, Naqvi IH, Ahmed A, Parveen S. Zika Virus-Induced Microcephaly and Its Possible Molecular Mechanism. Intervirology. 2016;59(3):152-8.

85. Shao Q, Herrlinger S, Yang SL, Lai F, Moore JM, Brindley MA, et al. Zika virus infection disrupts neurovascular development and results in postnatal microcephaly with brain damage. Development. 2016;143(22):4127-36.

86. Corona-Rivera JR, Corona-Rivera E, Romero-Velarde E, Hernandez-Rocha J, Bobadilla-Morales L, Corona-Rivera A. Report and review of the fetal brain disruption sequence. Eur $\mathrm{J}$ Pediatr. 2001;160(11):664-7.

87. Brasil P, Calvet GA, Siqueira AM, Wakimoto M, de Sequeira PC, Nobre A, et al. Zika Virus Outbreak in Rio de Janeiro, Brazil: Clinical Characterization, Epidemiological and Virological Aspects. PLoS Negl Trop Dis. 2016;10(4):e0004636.

88. Brasil P, Pereira JP, Jr., Moreira ME, Ribeiro Nogueira RM, Damasceno L, Wakimoto M, et al. Zika Virus Infection 


\section{The Unifying Effects of Maternal-Placental-Fetal Axis Dysregulation on Neurodevelopment Following Infectious and Toxic In Utero Insults}

in Pregnant Women in Rio de Janeiro. N Engl J Med. 2016;375(24):2321-34.

89. Wu KY, Zuo GL, Li XF, Ye Q, Deng YQ, Huang XY, et al. Vertical transmission of Zika virus targeting the radial glial cells affects cortex development of offspring mice. Cell Res. 2016;26(6):645-54.

90. Soares de Souza A, Moraes Dias C, Braga FD, Terzian AC, Estofolete CF, Oliani AH, et al. Fetal Infection by Zika Virus in the Third Trimester: Report of 2 Cases. Clin Infect Dis. 2016;63(12):16225.

91. Schwartz DA. The Origins and Emergence of Zika Virus, the Newest TORCH Infection: What's Old Is New Again. Arch Pathol Lab Med. 2017;141(1):18-25.

92. Faria NR, Azevedo Rdo S, Kraemer MU, Souza R, Cunha MS, Hill $\mathrm{SC}$, et al. Zika virus in the Americas: Early epidemiological and genetic findings. Science. 2016;352(6283):345-9.

93. Woods CG, Basto R. Microcephaly. Curr Biol. 2014;24(23):R1109-11.

94. Driggers RW, Ho CY, Korhonen EM, Kuivanen S, Jaaskelainen AJ, Smura $\mathrm{T}$, et al. Zika Virus Infection with Prolonged Maternal Viremia and Fetal Brain Abnormalities. N Engl J Med. 2016;374(22):2142-51.

95. Soares CN, Brasil P, Carrera RM, Sequeira P, de Filippis AB, Borges VA, et al. Fatal encephalitis associated with Zika virus infection in an adult. J Clin Virol. 2016;83:63-5.

96. Honein MA, Jamieson DJ. Monitoring and Preventing Congenital Zika Syndrome. N Engl J Med. 2016;375(24):2393-4.

97. Falcao MB, Cimerman S, Luz KG, Chebabo A, Brigido HA, Lobo IM, et al. Management of infection by the Zika virus. Ann Clin Microbiol Antimicrob. 2016;15(1):57.

98. Coyne CB, Lazear HM. Zika virus - reigniting the TORCH. Nat Rev Microbiol. 2016;14(11):707-15.

99. Gerardin P, Samperiz S, Ramful D, Boumahni B, Bintner M, Alessandri JL, et al. Neurocognitive outcome of children exposed to perinatal mother-tochild Chikungunya virus infection: the CHIMERE cohort study on Reunion Island. PLoS Negl Trop Dis. 2014;8(7):e2996.

100. O'Leary DR, Kuhn S, Kniss KL, Hinckley AF, Rasmussen SA, Pape WJ, et al. Birth outcomes following West Nile Virus infection of pregnant women in the United States: 2003-2004. Pediatrics. 2006;117(3):e537-45.

101. Conboy TJ, Pass RF, Stagno S, Britt WJ, Alford CA, McFarland CE, et al. Intellectual development in school-aged children with asymptomatic congenital cytomegalovirus infection. Pediatrics. 1986;77(6):801-6.

102. Hamel R, Dejarnac O, Wichit S, Ekchariyawat P, Neyret A, Luplertlop N, et al. Biology of Zika Virus Infection in Human Skin Cells. J Virol. 2015;89(17):8880-96.

103. Bayer A, Lennemann NJ, Ouyang Y, Bramley JC, Morosky S, Marques ET, Jr., et al. Type III Interferons Produced by Human Placental Trophoblasts Confer Protection against Zika Virus Infection. Cell Host Microbe. 2016;19(5):705-12.

104. El Costa H, Gouilly J, Mansuy JM, Chen Q, Levy C, Cartron G, et al. ZIKA virus reveals broad tissue and cell tropism during the first trimester of pregnancy. Sci Rep. 2016;6:35296.

105. Tabata T, Petitt M, Puerta-Guardo H, Michlmayr D, Wang C, Fang-Hoover $\mathrm{J}$, et al. Zika Virus Targets Different Primary Human Placental Cells, 


\section{The Unifying Effects of Maternal-Placental-Fetal Axis Dysregulation on Neurodevelopment Following Infectious and Toxic In Utero Insults}

Suggesting Two Routes for Vertical Transmission. Cell Host Microbe. 2016;20(2):155-66.

106. Li C, Xu D, Ye Q, Hong S, Jiang Y, Liu X, et al. Zika Virus Disrupts Neural Progenitor Development and Leads to Microcephaly in Mice. Cell Stem Cell. 2016;19(5):672.

107. Bayless NL, Greenberg RS, Swigut T, Wysocka J, Blish CA. Zika Virus Infection Induces Cranial Neural Crest Cells to Produce Cytokines at Levels Detrimental for Neurogenesis. Cell Host Microbe. 2016;20(4):423-8.

108. van der Linden V, Filho EL, Lins OG, van der Linden A, Aragao Mde F, Brainer-Lima AM, et al. Congenital Zika syndrome with arthrogryposis: retrospective case series study. BMJ. 2016;354:i3899.

109. Walter LT, Higa GS, Ikebara JM, Vedovello D, Salvador FS, Takada SH, et al. Evaluation of Possible Consequences of Zika Virus Infection in the Developing Nervous System. Mol Neurobiol. 2017. 110. Zhang F, Hammack C, Ogden SC, Cheng Y, Lee EM, Wen Z, et al. Molecular signatures associated with ZIKV exposure in human cortical neural progenitors. Nucleic Acids Res. 2016;44(18):8610-20.

111. Nowakowski TJ, Pollen AA, Di Lullo E, Sandoval-Espinosa C, Bershteyn M, Kriegstein AR. Expression Analysis Highlights AXL as a Candidate Zika Virus Entry Receptor in Neural Stem Cells. Cell Stem Cell. 2016;18(5):591-6.

112. Perera-Lecoin M, Meertens L, Carnec X, Amara A. Flavivirus entry receptors: an update. Viruses. 2013;6(1):69-88.

113. Garcez PP, Loiola EC, Madeiro da Costa R, Higa LM, Trindade P, Delvecchio R, et al. Zika virus impairs growth in human neurospheres and brain organoids. Science. 2016;352(6287):8168.

114. Tang H, Hammack C, Ogden SC, Wen Z, Qian X, Li Y, et al. Zika Virus Infects Human Cortical Neural Progenitors and Attenuates Their Growth. Cell Stem Cell. 2016;18(5):587-90.

115. Noronha L, Zanluca C, Azevedo ML, Luz KG, Santos CN. Zika virus damages the human placental barrier and presents marked fetal neurotropism. Mem Inst Oswaldo Cruz. 2016;111(5):287-93.

116. Dowall SD, Graham VA, Rayner E, Atkinson B, Hall G, Watson RJ, et al. A Susceptible Mouse Model for Zika Virus Infection. PLoS Negl Trop Dis. 2016;10(5):e0004658.

117. Bell TM, Field EJ, Narang HK. Zika virus infection of the central nervous system of mice. Arch Gesamte Virusforsch. 1971;35(2):183-93.

118. Miner JJ, Diamond MS. Understanding How Zika Virus Enters and Infects Neural Target Cells. Cell Stem Cell. 2016;18(5):559-60.

119. Miner JJ, Diamond MS. Zika Virus Pathogenesis and Tissue Tropism. Cell Host Microbe. 2017;21(2):134-42.

120. Paulozzi LJ, Mack KA, Hockenberry JM. Variation among states in prescribing of opioid pain relievers and benzodiazepines--United States, 2012. J Safety Res. 2014;51:125-9.

121. Rudd RA, Seth P, David F, Scholl L. Increases in Drug and Opioid-Involved Overdose Deaths - United States, 20102015. MMWR Morb Mortal Wkly Rep. 2016;65(5051):1445-52.

122. Allen JD, Casavant MJ, Spiller HA, Chounthirath T, Hodges NL, Smith GA. Prescription Opioid Exposures Among Children and Adolescents in the United States: 2000-2015. Pediatrics. 2017. 


\section{The Unifying Effects of Maternal-Placental-Fetal Axis Dysregulation on Neurodevelopment Following Infectious and Toxic In Utero Insults}

123. Patrick SW, Schiff DM, Committee On Substance USE, Prevention. A Public Health Response to Opioid Use in Pregnancy. Pediatrics. 2017;139(3).

124. Patrick SW, Dudley J, Martin PR, Harrell FE, Warren MD, Hartmann KE, et al. Prescription opioid epidemic and infant outcomes. Pediatrics. 2015;135(5):842-50. 125. Kocherlakota P. Neonatal abstinence syndrome. Pediatrics. 2014;134(2):e547-61.

126. Patrick SW, Schumacher RE, Benneyworth BD, Krans EE, McAllister JM, Davis MM. Neonatal abstinence syndrome and associated health care expenditures: United States, 2000-2009. JAMA. 2012;307(18):1934-40.

127. McQueen K, Murphy-Oikonen J. Neonatal Abstinence Syndrome. N Engl J Med. 2016;375(25):2468-79.

128. Ailes EC, Dawson AL, Lind JN, Gilboa SM, Frey MT, Broussard CS, et al. Opioid prescription claims among women of reproductive age--United States, 20082012. MMWR Morb Mortal Wkly Rep. 2015;64(2):37-41.

129. Desai RJ, Hernandez-Diaz S, Bateman BT, Huybrechts KF. Increase in prescription opioid use during pregnancy among Medicaid-enrolled women. Obstet Gynecol. 2014;123(5):997-1002.

130. Epstein RA, Bobo WV, Martin PR, Morrow JA, Wang W, Chandrasekhar $\mathrm{R}$, et al. Increasing pregnancy-related use of prescribed opioid analgesics. Ann Epidemiol. 2013;23(8):498-503.

131. Lejeune C, Simmat-Durand L, Gourarier L, Aubisson S, Groupe d'Etudes Grossesse et A. Prospective multicenter observational study of 260 infants born to 259 opiate-dependent mothers on methadone or high-dose buprenophine substitution. Drug Alcohol Depend. 2006;82(3):250-7.
132. Williams J. Basic Opioid Pharmacology. Rev Pain. 2008;1(2):2-5. 133. Le Merrer J, Becker JA, Befort K, Kieffer BL. Reward processing by the opioid system in the brain. Physiol Rev. 2009;89(4):1379-412.

134. Sirnes E, Oltedal L, Bartsch H, Eide GE, Elgen IB, Aukland SM. Brain morphology in school-aged children with prenatal opioid exposure: A structural MRI study. Early Hum Dev. 2017;106107:33-9.

135. Nekhayeva IA, Nanovskaya TN, Deshmukh SV, Zharikova OL, Hankins GD, Ahmed MS. Bidirectional transfer of methadone across human placenta. Biochem Pharmacol. 2005;69(1):187-97. 136. Gerdin E, Rane A, Lindberg B. Transplacental transfer of morphine in man. J Perinat Med. 1990;18(4):305-12.

137. Almario CV, Seligman NS, Dysart $\mathrm{KC}$, Berghella V, Baxter JK. Risk factors for preterm birth among opiate-addicted gravid women in a methadone treatment program. Am J Obstet Gynecol. 2009;201(3):326 e1-6.

138. Martin JA, Hamilton BE, Sutton PD, Ventura SJ, Menacker F, Kirmeyer S. Births: final data for 2004. Natl Vital Stat Rep. 2006;55(1):1-101.

139. Nygaard E, Moe V, Slinning K, Walhovd KB. Longitudinal cognitive development of children born to mothers with opioid and polysubstance use. Pediatr Res. 2015;78(3):330-5.

140. Konijnenberg C, Melinder A. Executive function in preschool children prenatally exposed to methadone or buprenorphine. Child Neuropsychol. 2015;21(5):570-85.

141. Hunt RW, Tzioumi D, Collins E, Jeffery HE. Adverse neurodevelopmental outcome of infants exposed to opiate inutero. Early Hum Dev. 2008;84(1):29-35. 


\section{The Unifying Effects of Maternal-Placental-Fetal Axis Dysregulation on Neurodevelopment Following Infectious and Toxic In Utero Insults}

142. Ross EJ, Graham DL, Money KM, Stanwood GD. Developmental consequences of fetal exposure to drugs: what we know and what we still must Jastrzab LE, Mackey SC. Prescription opioid analgesics rapidly change the human brain. Pain. 2011;152(8):1803-10.

144. Upadhyay J, Maleki N, Potter J, Elman I, Rudrauf D, Knudsen J, et al. Alterations in brain structure and functional connectivity in prescription opioid-dependent patients. Brain. 2010;133(Pt 7):2098-114.

145. De Felice C, Toti P, Laurini RN, Stumpo M, Picciolini E, Todros T, et al. Early neonatal brain injury in histologic chorioamnionitis. J $\quad$ Pediatr. 2001;138(1):101-4.

146. Galinsky R, Polglase GR, Hooper SB, Black MJ, Moss TJ. The consequences of chorioamnionitis: preterm birth and effects on development. J Pregnancy. 2013;2013:412831.

147. Hudak ML, Tan RC, Committee On D, Committee On F, Newborn, American Academy of P. Neonatal drug withdrawal. Pediatrics. 2012;129(2):e54060 .

148. Patrick SW, Davis MM, Lehman CU, Cooper WO. Increasing incidence and geographic distribution of neonatal abstinence syndrome: United States 2009 to 2012. J Perinatol. 2015;35(8):667.

149. Davies H, Gilbert R, Johnson K, Petersen I, Nazareth I, O'Donnell M, et al. Neonatal drug withdrawal syndrome: cross-country comparison using hospital administrative data in England, the USA, Western Australia and Ontario, Canada. Arch Dis Child Fetal Neonatal Ed. 2016;101(1):F26-30.

150. Manchikanti L, Singh A. Therapeutic opioids: a ten-year perspective on the complexities and complications of the escalating use, abuse, learn. Neuropsychopharmacology. 2015;40(1):61-87.

143. Younger JW, Chu LF, D'Arcy NT, Trott KE, and nonmedical use of opioids. Pain Physician. 2008;11(2 Suppl):S63-88.

151. Jones HE, Johnson RE, Jasinski DR, O'Grady KE, Chisholm CA, Choo $\mathrm{RE}$, et al. Buprenorphine versus methadone in the treatment of pregnant opioid-dependent patients: effects on the neonatal abstinence syndrome. Drug Alcohol Depend. 2005;79(1):1-10.

152. Malek A, Obrist C, Wenzinger S, von Mandach U. The impact of cocaine and heroin on the placental transfer of methadone. Reprod Biol Endocrinol. 2009; 7:61.

153. Kandall SR, Gartner LM. Late presentation of drug withdrawal symptoms in newborns. Am J Dis Child. 1974;127(1):58-61.

154. Zimmermann-Baer U, Notzli U, Rentsch K, Bucher HU. Finnegan neonatal abstinence scoring system: normal values for first 3 days and weeks 5-6 in non-addicted infants. Addiction. 2010;105(3):524-8.

155. Sarkar S, Donn SM. Management of neonatal abstinence syndrome in neonatal intensive care units: a national survey. J Perinatol. 2006;26(1):15-7.

156. Finnegan LP, Connaughton JF, Jr., Kron RE, Emich JP. Neonatal abstinence syndrome: assessment and management. Addict Dis. 1975;2(1-2):141-58.

157. D'Apolito KC. Assessing neonates for neonatal abstinence: are you reliable? J Perinat Neonatal Nurs. 2014;28(3):22031.

158. Stover MW, Davis JM. Opioids in pregnancy and neonatal abstinence syndrome. Semin Perinatol. 2015;39(7):561-5. 


\section{The Unifying Effects of Maternal-Placental-Fetal Axis Dysregulation on Neurodevelopment Following Infectious and Toxic In Utero Insults}

159. Bagley SM, Wachman EM, Holland E, Brogly SB. Review of the assessment and management of neonatal abstinence syndrome. Addict Sci Clin Pract. 2014;9(1):19.

160. Rubinchik-Stern M, Eyal S. Drug Interactions at the Human Placenta: What is the Evidence? Front Pharmacol. 2012;3:126.

161. Nanovskaya TN, Nekhayeva IA, Hankins GD, Ahmed MS. Transfer of methadone across the dually perfused preterm human placental lobule. Am J Obstet Gynecol. 2008;198(1):126 e1-4.

162. Jansson LM, Velez ML. Infants of drug-dependent mothers. Pediatr Rev. 2011;32(1):5-12; quiz -3.

163. Jones HE, Deppen K, Hudak ML, Leffert L, McClelland C, Sahin L, et al. Clinical care for opioid-using pregnant and postpartum women: the role of obstetric providers. Am J Obstet Gynecol. 2014;210(4):302-10.

164. Walhovd KB, Moe V, Slinning K, Due-Tonnessen P, Bjornerud A, Dale AM, et al. Volumetric cerebral characteristics of children exposed to opiates and other substances in utero. Neuroimage. 2007;36(4):1331-44.

165. Bush G, Valera EM, Seidman LJ. Functional neuroimaging of attentiondeficit/hyperactivity disorder: a review and suggested future directions. Biol Psychiatry. 2005;57(11):1273-84.

166. Seidman LJ, Valera EM, Makris N. Structural brain imaging of attentiondeficit/hyperactivity disorder. Biol Psychiatry. 2005;57(11):1263-72.

167. Logan BA, Brown MS, Hayes MJ. Neonatal abstinence syndrome: treatment and pediatric outcomes. Clin Obstet Gynecol. 2013;56(1):186-92.

168. Hu S, Sheng WS, Lokensgard JR, Peterson PK. Morphine induces apoptosis of human microglia and neurons. Neuropharmacology. 2002;42(6):829-36. 169. Stiene-Martin A, Knapp PE, Martin K, Gurwell JA, Ryan S, Thornton $\mathrm{SR}$, et al. Opioid system diversity in developing neurons, astroglia, and oligodendroglia in the subventricular zone and striatum: impact on gliogenesis in vivo. Glia. 2001;36(1):78-88.

170. Lu R, Liu X, Long H, Ma L. Effects of prenatal cocaine and heroin exposure on neuronal dendrite morphogenesis and spatial recognition memory in mice. Neurosci Lett. 2012;522(2):128-33.

171. Vestal-Laborde AA, Eschenroeder AC, Bigbee JW, Robinson SE, SatoBigbee C. The opioid system and brain development: effects of methadone on the oligodendrocyte lineage and the early stages of myelination. Dev Neurosci. 2014;36(5):409-21.

172. Popova S, Lange S, Probst C, Gmel G, Rehm J. Estimation of national, regional, and global prevalence of alcohol use during pregnancy and fetal alcohol syndrome: a systematic review and metaanalysis. Lancet Glob Health. 2017;5(3):e290-e9.

173. Popova S, Lange S, Probst C, Parunashvili N, Rehm J. Prevalence of alcohol consumption during pregnancy and Fetal Alcohol Spectrum Disorders among the general and Aboriginal populations in Canada and the United States. Eur J Med Genet. 2017;60(1):3248.

174. Green PP, McKnight-Eily LR, Tan CH, Mejia R, Denny CH. Vital Signs: Alcohol-Exposed Pregnancies--United States, 2011-2013. MMWR Morb Mortal Wkly Rep. 2016;65(4):91-7.

175. Floyd RL, Sidhu JS. Monitoring prenatal alcohol exposure. Am J Med 


\section{The Unifying Effects of Maternal-Placental-Fetal Axis Dysregulation on Neurodevelopment Following Infectious and Toxic In Utero Insults}

Genet C Semin Med Genet. 2004;127C(1):3-9.

176. Tan $\mathrm{CH}$, Denny $\mathrm{CH}$, Cheal NE, Sniezek JE, Kanny D. Alcohol use and binge drinking among women of childbearing age - United States, 20112013. MMWR Morb Mortal Wkly Rep. 2015;64(37):1042-6.

177. Stade B, Ali A, Bennett D, Campbell D, Johnston M, Lens C, et al. The burden of prenatal exposure to alcohol: revised measurement of cost. Can J Clin Pharmacol. 2009;16(1):e91-102.

178. Stade BC, Bailey C, Dzendoletas D, Sgro M, Dowswell T, Bennett D. Psychological and/or educational interventions for reducing alcohol consumption in pregnant women and women planning pregnancy. Cochrane Database Syst Rev. 2009(2):CD004228.

179. May PA, Baete A, Russo J, Elliott AJ, Blankenship J, Kalberg WO, et al. Prevalence and characteristics of fetal alcohol spectrum disorders. Pediatrics. 2014;134(5):855-66.

180. Chudley AE, Conry J, Cook JL, Loock C, Rosales T, LeBlanc N, et al. Fetal alcohol spectrum disorder: Canadian guidelines for diagnosis. CMAJ. 2005;172(5 Suppl):S1-S21.

181. Riley EP, Infante MA, Warren KR. Fetal alcohol spectrum disorders: an overview. Neuropsychol Rev. 2011;21(2):73-80.

182. Cook JL, Green CR, Lilley CM, Anderson SM, Baldwin ME, Chudley AE, et al. Fetal alcohol spectrum disorder: a guideline for diagnosis across the lifespan. CMAJ. 2016;188(3):191-7.

183. Jones KL, Smith DW. Recognition of the fetal alcohol syndrome in early infancy. Lancet. 1973;302(7836):9991001.

184. Bertrand J, Interventions for Children with Fetal Alcohol Spectrum
Disorders Research C. Interventions for children with fetal alcohol spectrum disorders (FASDs): overview of findings for five innovative research projects. Res Dev Disabil. 2009;30(5):986-1006.

185. Kesmodel U, Wisborg K, Olsen SF, Henriksen TB, Secher NJ. Moderate alcohol intake during pregnancy and the risk of stillbirth and death in the first year of life. Am J Epidemiol. 2002;155(4):30512.

186. Kesmodel U, Wisborg K, Olsen SF, Henriksen TB, Secher NJ. Moderate alcohol intake in pregnancy and the risk of spontaneous abortion. Alcohol Alcohol. 2002;37(1):87-92.

187. Albertsen K, Andersen AM, Olsen J, Gronbaek M. Alcohol consumption during pregnancy and the risk of preterm delivery. Am J Epidemiol. 2004;159(2):155-61.

188. Patra J, Bakker R, Irving H, Jaddoe VW, Malini S, Rehm J. Doseresponse relationship between alcohol consumption before and during pregnancy and the risks of low birthweight, preterm birth and small for gestational age (SGA)a systematic review and meta-analyses. BJOG. 2011;118(12):1411-21.

189. Burd L, Blair J, Dropps K. Prenatal alcohol exposure, blood alcohol concentrations and alcohol elimination rates for the mother, fetus and newborn. $\mathbf{J}$ Perinatol. 2012;32(9):652-9.

190. Burd L, Roberts D, Olson M, Odendaal H. Ethanol and the placenta: A review. J Matern Fetal Neonatal Med. 2007;20(5):361-75.

191. Streissguth AP, Bookstein FL, Barr HM, Sampson PD, O'Malley K, Young JK. Risk factors for adverse life outcomes in fetal alcohol syndrome and fetal alcohol effects. J Dev Behav Pediatr. 2004;25(4):228-38. 


\section{The Unifying Effects of Maternal-Placental-Fetal Axis Dysregulation on Neurodevelopment Following Infectious and Toxic In Utero Insults}

192. Streissguth AP, O'Malley K. Neuropsychiatric implications and longterm consequences of fetal alcohol spectrum disorders. Semin Clin Neuropsychiatry. 2000;5(3):177-90.

193. Lebel C, Mattson SN, Riley EP, Jones KL, Adnams CM, May PA, et al. A longitudinal study of the long-term consequences of drinking during pregnancy: heavy in utero alcohol exposure disrupts the normal processes of brain development. J Neurosci. 2012;32(44):15243-51.

194. Lebel C, Roussotte F, Sowell ER. Imaging the impact of prenatal alcohol exposure on the structure of the developing human brain. Neuropsychol Rev. 2011;21(2):102-18.

195. Bookstein FL, Sampson PD, Connor PD, Streissguth AP. Midline corpus callosum is a neuroanatomical focus of fetal alcohol damage. Anat Rec. 2002;269(3):162-74.

196. Gautam P, Lebel C, Narr KL, Mattson SN, May PA, Adnams CM, et al. Volume changes and brain-behavior relationships in white matter and subcortical gray matter in children with prenatal alcohol exposure. Hum Brain Mapp. 2015;36(6):2318-29.

197. Treit S, Lebel C, Baugh L, Rasmussen C, Andrew G, Beaulieu C. Longitudinal MRI reveals altered trajectory of brain development during childhood and adolescence in fetal alcohol spectrum disorders. J Neurosci. 2013;33(24):10098-109.

198. Wozniak JR, Mueller BA, Bell CJ, Muetzel RL, Hoecker HL, Boys CJ, et al. Global functional connectivity abnormalities in children with fetal alcohol spectrum disorders. Alcohol Clin Exp Res. 2013;37(5):748-56.

199. Wozniak JR, Mueller BA, Chang PN, Muetzel RL, Caros L, Lim KO.
Diffusion tensor imaging in children with fetal alcohol spectrum disorders. Alcohol Clin Exp Res. 2006;30(10):1799-806.

200. Wozniak JR, Muetzel RL, Mueller BA, McGee CL, Freerks MA, Ward EE, et al. Microstructural corpus callosum anomalies in children with prenatal alcohol exposure: an extension of previous diffusion tensor imaging findings. Alcohol Clin Exp Res. 2009;33(10):1825-35.

201. Louth EL, Bignell W, Taylor CL, Bailey CD. Developmental Ethanol Exposure Leads to Long-Term Deficits in Attention and Its Underlying Prefrontal Circuitry. eNeuro. 2016;3(5).

202. Del Campo M, Jones KL. A review of the physical features of the fetal alcohol spectrum disorders. Eur J Med Genet. 2017;60(1):55-64.

203. Arcangeli T, Thilaganathan B, Hooper R, Khan KS, Bhide A. Neurodevelopmental delay in small babies at term: a systematic review. Ultrasound Obstet Gynecol. 2012;40(3):267-75.

204. Jacobson SW, Jacobson JL, Molteno CD, Warton CM, Wintermark P, Hoyme HE, et al. Heavy prenatal alcohol exposure is related to smaller corpus callosum in newborn MRI scans. Alcohol Clin Exp Res. 2017.

205. Thompson DK, Inder TE, Faggian N, Johnston L, Warfield SK, Anderson PJ, et al. Characterization of the corpus callosum in very preterm and full-term infants utilizing MRI. Neuroimage. 2011;55(2):479-90.

206. Thompson DK, Inder TE, Faggian N, Warfield SK, Anderson PJ, Doyle LW, et al. Corpus callosum alterations in very preterm infants: perinatal correlates and 2 year neurodevelopmental outcomes. Neuroimage. 2012;59(4):3571-81.

207. Taylor PA, Jacobson SW, van der Kouwe A, Molteno CD, Chen G, 


\section{The Unifying Effects of Maternal-Placental-Fetal Axis Dysregulation on Neurodevelopment Following Infectious and Toxic In Utero Insults}

Wintermark P, et al. A DTI-based tractography study of effects on brain structure associated with prenatal alcohol exposure in newborns. Hum Brain Mapp. 2015;36(1):170-86.

208. Clarren SK, Smith DW. The fetal alcohol syndrome. N Engl J Med. 1978;298(19):1063-7.

209. Fontaine CJ, Patten AR, Sickmann HM, Helfer JL, Christie BR. Effects of pre-natal alcohol exposure on hippocampal synaptic plasticity: Sex, age and methodological considerations. Neurosci Biobehav Rev. 2016;64:12-34. 210. Lo JO, Schabel MC, Roberts VH, Wang X, Lewandowski KS, Grant KA, et al. First trimester alcohol exposure alters placental perfusion and fetal oxygen availability affecting fetal growth and development in a non-human primate model. Am J Obstet Gynecol. 2017;216(3):302 e1- e8.

211. Acevedo CG, Carrasco G, Burotto M, Rojas S, Bravo I. Ethanol inhibits Larginine uptake and enhances NO formation in human placenta. Life Sci. 2001;68(26):2893-903.

212. Fisher SE, Atkinson M, Burnap JK, Jacobson S, Sehgal PK, Scott W, et al. Ethanol-associated selective fetal malnutrition: a contributing factor in the fetal alcohol syndrome. Alcohol Clin Exp Res. 1982;6(2):197-201.

213. Heller M, Burd L. Review of ethanol dispersion, distribution, and elimination from the fetal compartment. Birth Defects Res A Clin Mol Teratol. 2014;100(4):277-83.

214. Nava-Ocampo AA, VelazquezArmenta Y, Brien JF, Koren G. Elimination kinetics of ethanol in pregnant women. Reprod Toxicol. 2004;18(4):613-7.

215. de Wit M, Goldberg A, Chelmow D. Alcohol use disorders and hospital- acquired infections in women undergoing cesarean delivery. Obstet Gynecol. 2013;122(1):72-8.

216. Davies M. The role of GABAA receptors in mediating the effects of alcohol in the central nervous system. J Psychiatry Neurosci. 2003;28(4):263-74.

217. Dzhala VI, Talos DM, Sdrulla DA, Brumback AC, Mathews GC, Benke TA, et al. NKCC1 transporter facilitates seizures in the developing brain. Nat Med. 2005;11(11):1205-13.

218. Kahle KT, Deeb TZ, Puskarjov M, Silayeva L, Liang B, Kaila K, et al. Modulation of neuronal activity by phosphorylation of the $\mathrm{K}-\mathrm{Cl}$ cotransporter KCC2. Trends Neurosci. 2013;36(12):726-37.

219. Kaila K, Price TJ, Payne JA, Puskarjov M, Voipio J. Cation-chloride cotransporters in neuronal development, plasticity and disease. Nat Rev Neurosci. 2014;15(10):637-54.

220. Jantzie LL, Getsy PM, Firl DJ, Wilson CG, Miller RH, Robinson S. Erythropoietin attenuates loss of potassium chloride co-transporters following prenatal brain injury. Mol Cell Neurosci. 2014;61:152-62.

221. Chau V, McFadden DE, Poskitt KJ, Miller SP. Chorioamnionitis in the pathogenesis of brain injury in preterm infants. Clin Perinatol. 2014;41(1):83103.

222. Conti N, Torricelli M, Voltolini C, Vannuccini S, Clifton VL, Bloise E, et al. Term histologic chorioamnionitis: a heterogeneous condition. Eur J Obstet Gynecol Reprod Biol. 2015;188:34-8.

223. Lee J, Kim JS, Park JW, Park CW, Park JS, Jun JK, et al. Chronic chorioamnionitis is the most common placental lesion in late preterm birth. Placenta. 2013;34(8):681-9. 


\section{The Unifying Effects of Maternal-Placental-Fetal Axis Dysregulation on Neurodevelopment Following Infectious and Toxic In Utero Insults}

224. Lee SM, Park JW, Kim BJ, Park $\mathrm{CW}$, Park JS, Jun JK, et al. Acute histologic chorioamnionitis is a risk factor for adverse neonatal outcome in late preterm birth after preterm premature rupture of membranes. PLoS One. 2013;8(12):e79941.

225. Pappas A, Kendrick DE, Shankaran S, Stoll BJ, Bell EF, Laptook $\mathrm{AR}$, et al. Chorioamnionitis and early childhood outcomes among extremely low-gestational-age neonates. JAMA Pediatr. 2014;168(2):137-47.

226. Ramsey PS, Lieman JM, Brumfield CG, Carlo W. Chorioamnionitis increases neonatal morbidity in pregnancies complicated by preterm premature rupture of membranes. Am J Obstet Gynecol. 2005;192(4):11626.

227. Romero R, Chaemsaithong $P$, Korzeniewski SJ, Tarca AL, Bhatti G, Xu $\mathrm{Z}$, et al. Clinical chorioamnionitis at term II: the intra-amniotic inflammatory response. J Perinat Med. 2015.

228. Shevell A, Wintermark P, Benini R, Shevell M, Oskoui M. Chorioamnionitis and cerebral palsy: lessons from a patient registry. Eur $\mathbf{J}$ Paediatr Neurol. 2014;18(3):301-7.

229. Soraisham AS, Trevenen C, Wood S, Singhal N, Sauve R. Histological chorioamnionitis and neurodevelopmental outcome in preterm infants. J Perinatol. 2013;33(1):70-5.

230. Wu YW, Colford JM, Jr. Chorioamnionitis as a risk factor for cerebral palsy: A meta-analysis. JAMA. 2000;284(11):1417-24.

231. Wu YW, Escobar GJ, Grether JK, Croen LA, Greene JD, Newman TB. Chorioamnionitis and cerebral palsy in term and near-term infants. JAMA. 2003;290(20):2677-84.
232. Goldenberg RL, Hauth JC, Andrews WW. Intrauterine infection and preterm delivery. $\mathrm{N}$ Engl $\mathrm{J}$ Med. 2000;342(20):1500-7.

233. Blencowe $\mathrm{H}$, Cousens $\mathrm{S}$, Oestergaard MZ, Chou D, Moller AB, Narwal R, et al. National, regional, and worldwide estimates of preterm birth rates in the year 2010 with time trends since 1990 for selected countries: a systematic analysis and implications. Lancet. 2012;379(9832):2162-72.

234. Robinson S. Systemic prenatal insults disrupt telencephalon development: Implications for treatment. Epilepsy Beh. 2005;7(3):345-63.

235. Robinson S, Li Q, Dechant A, Cohen ML. Neonatal loss of gammaaminobutyric acid pathway expression after human perinatal brain injury. J Neurosurg. 2006;104(6 Suppl):396-408.

236. Robinson S, Mikolaenko I, Thompson I, Cohen ML, Goyal M. Loss of cation-chloride cotransporter expression in preterm infants with white matter lesions: implications for the pathogenesis of epilepsy. J Neuropathol Exp Neurol. 2010;69(6):565-72.

237. Anderson PJ. Neuropsychological outcomes of children born very preterm. Semin Fetal Neonatal Med. 2014;19(2):90-6.

238. Blencowe H, Lee AC, Cousens $\mathrm{S}$, Bahalim A, Narwal R, Zhong N, et al. Preterm birth-associated neurodevelopmental impairment estimates at regional and global levels for 2010. Pediatr Res. 2013;74 Suppl 1:17-34.

239. Mwaniki MK, Atieno M, Lawn JE, Newton CR. Long-term neurodevelopmental outcomes after intrauterine and neonatal insults: a systematic review. Lancet. 2012;379(9814):445-52. 


\section{The Unifying Effects of Maternal-Placental-Fetal Axis Dysregulation on Neurodevelopment Following Infectious and Toxic In Utero Insults}

240. Vos RC, Becher JG, Ketelaar M, Smits DW, Voorman JM, Tan SS, et al. Developmental trajectories of daily activities in children and adolescents with cerebral palsy. Pediatrics. 2013;132(4):e915-23.

241. McCormick MC, Behrman RE. The quiet epidemic of premature birth: commentary on a recent Institute of Medicine report. Ambul Pediatr. 2007;7(1):8-9.

242. Chen A, Oster E, Williams H. Why Is Infant Mortality Higher in the United States Than in Europe? Am Econ J Econ Policy. 2016;8(2):89-124.

243. Hodnett ED, Fredericks S, Weston $\mathrm{J}$. Support during pregnancy for women at increased risk of low birthweight babies. Cochrane Database Syst Rev. 2010(6):CD000198.

244. Wintermark P, Boyd T, Gregas MC, Labrecque M, Hansen A. Placental pathology in asphyxiated newborns meeting the criteria for therapeutic hypothermia. Am J Obstet Gynecol. 2010;203(6):579 e1-9.

245. Lee SM, Lee KA, Kim SM, Park $\mathrm{CW}$, Yoon $\mathrm{BH}$. The risk of intra-amniotic infection, inflammation and histologic chorioamnionitis in term pregnant women with intact membranes and labor. Placenta. 2011;32(7):516-21.

246. Lachapelle J, Chen M, Oskoui M, Ali N, Brown R, Wintermark P. Placental pathology in asphyxiated newborns treated with therapeutic hypothermia. J Neonatal Perinatal Med. 2015.

247. Anblagan D, Pataky R, Evans MJ, Telford EJ, Serag A, Sparrow S, et al. Association between preterm brain injury and exposure to chorioamnionitis during fetal life. Sci Rep. 2016;6:37932.

248. Lee J, Croen LA, Backstrand KH, Yoshida CK, Henning LH, Lindan C, et al. Maternal and infant characteristics associated with perinatal arterial stroke in the infant. JAMA. 2005;293(6):723-9.

249. Lee J, Croen LA, Lindan C, Nash $\mathrm{KB}$, Yoshida CK, Ferriero DM, et al. Predictors of outcome in perinatal arterial stroke: a population-based study. Ann Neurol. 2005;58(2):303-8.

250. Wu YW, Lynch JK, Nelson KB. Perinatal arterial stroke: understanding mechanisms and outcomes. Semin Neurol. 2005;25(4):424-34.

251. Sweeney EL, Dando SJ, Kallapur SG, Knox CL. The Human Ureaplasma Species as Causative Agents of Chorioamnionitis. Clin Microbiol Rev. 2017;30(1):349-79.

252. Tita AT, Andrews WW. Diagnosis and management of clinical chorioamnionitis. Clin Perinatol. 2010;37(2):339-54.

253. Dowling O, Chatterjee PK, Gupta M, Tam Tam HB, Xue X, Lewis D, et al. Magnesium sulfate reduces bacterial LPSinduced inflammation at the maternalfetal interface. Placenta. 2012;33(5):3928.

254. Redline RW, Minich N, Taylor HG, Hack M. Placental lesions as predictors of cerebral palsy and abnormal neurocognitive function at school age in extremely low birth weight infants $(<1$ kg). Pediatr Dev Pathol. 2007;10(4):28292.

255. Yoon BH, Romero R, Yang SH, Jun JK, Kim IO, Choi JH, et al. Interleukin-6 concentrations in umbilical cord plasma are elevated in neonates with white matter lesions associated with periventricular leukomalacia. Am J Obstet Gynecol. 1996;174(5):1433-40.

256. Kaukola T, Herva R, Perhomaa M, Paakko E, Kingsmore S, Vainionpaa L, et al. Population cohort associating chorioamnionitis, cord inflammatory cytokines and neurologic outcome in very 


\section{The Unifying Effects of Maternal-Placental-Fetal Axis Dysregulation on Neurodevelopment Following Infectious and Toxic In Utero Insults}

preterm, extremely low birth weight infants. Pediatr Res. 2006;59(3):478-83.

257. Watterberg KL, Demers LM, Scott SM, Murphy S. Chorioamnionitis and early lung inflammation in infants in whom bronchopulmonary dysplasia develops. Pediatrics. 1996;97(2):210-5.

258. Chau V, Synnes A, Grunau RE, Poskitt KJ, Brant R, Miller SP. Abnormal brain maturation in preterm neonates associated with adverse developmental outcomes. Neurology. 2013;81(24):20829.

259. Redline RW. Disorders of placental circulation and the fetal brain. Clin Perinatol. 2009;36(3):549-59.

260. Redline RW. Correlation of Placental Pathology with Perinatal Brain Injury. Surg Pathol Clin. 2013;6(1):15380.

261. Redline RW, O'Riordan MA. Placental lesions associated with cerebral palsy and neurologic impairment following term birth. Archives of pathology \& laboratory medicine. 2000;124(12):1785-91.

262. Dueck CC, Grynspan D, Eisenstat $\mathrm{DD}$, Caces R, Rafay MF. Ischemic perinatal stroke secondary to chorioamnionitis: a histopathological case presentation. J Child Neurol. 2009;24(12):1557-60.

263. Iams JD, Romero R, Culhane JF, Goldenberg RL. Primary, secondary, and tertiary interventions to reduce the morbidity and mortality of preterm birth. Lancet. 2008;371(9607):164-75.

264. Czikk MJ, McCarthy FP, Murphy KE. Chorioamnionitis: from pathogenesis to treatment. Clin Microbiol Infect. 2011;17(9):1304-11.

265. Lahra MM, Jeffery HE. A fetal response to chorioamnionitis is associated with early survival after preterm birth. Am J Obstet Gynecol. 2004;190(1):147-51.
266. Goldenberg RL, Culhane JF, Iams JD, Romero R. Epidemiology and causes of preterm birth. Lancet. 2008;371(9606):75-84.

267. Catov JM, Scifres CM, Caritis SN, Bertolet M, Larkin J, Parks WT. Neonatal outcomes following preterm birth classified according to placental features. Am J Obstet Gynecol. 2017.

268. Kaufmann P. Influence of ischemia and artificial perfusion on placental ultrastructure and morphometry. Contrib Gynecol Obstet. 1985;13:18-26.

269. Kumazaki K, Nakayama M, Sumida Y, Ozono K, Mushiake S, Suehara N, et al. Placental features in preterm infants with periventricular leukomalacia. Pediatrics. 2002;109(4):650-5.

270. Lahra MM, Beeby PJ, Jeffery HE. Maternal versus fetal inflammation and respiratory distress syndrome: a 10-year hospital cohort study. Arch Dis Child Fetal Neonatal Ed. 2009;94(1):F13-6.

271. Redline RW. Inflammatory responses in the placenta and umbilical cord. Semin Fetal Neonatal Med. 2006;11(5):296-301.

272. Abdulkadir AA, Kimimasa T, Bell MJ, Macpherson TA, Keller BB, Yanowitz TD. Placental inflammation and fetal hemodynamics in a rat model of chorioamnionitis. Pediatr Res. 2010;68(6):513-8.

273. Dammann O, Leviton A. Maternal intrauterine infection, cytokines, and brain damage in the preterm newborn. Pediatr Res. 1997;42(1):1-8.

274. Dammann O, Leviton A. Intermittent or sustained systemic inflammation and the preterm brain. Pediatr Res. 2014;75(3):376-80.

275. Leviton A, Fichorova R, Yamamoto Y, Allred EN, Dammann O, Hecht $J$, et al. Inflammation-related 


\section{The Unifying Effects of Maternal-Placental-Fetal Axis Dysregulation on Neurodevelopment Following Infectious and Toxic In Utero Insults}

proteins in the blood of extremely low gestational age newborns. The contribution of inflammation to the appearance of developmental regulation. Cytokine. 2011;53(1):66-73.

276. Dziegielewska KM, Moller JE, Potter AM, Ek J, Lane MA, Saunders NR. Acute-phase cytokines IL-1beta and TNFalpha in brain development. Cell Tissue Res. 2000;299(3):335-45.

277. Timmons BC, Fairhurst AM, Mahendroo MS. Temporal changes in myeloid cells in the cervix during pregnancy and parturition. J Immunol. 2009;182(5):2700-7.

278. Muglia LJ, Katz M. The enigma of spontaneous preterm birth. N Engl J Med. 2010;362(6):529-35.

279. Bastek JA, Brown AG, Anton L, Srinivas SK, D'Addio A, Elovitz MA. Biomarkers of inflammation and placental dysfunction are associated with subsequent preterm birth. J Matern Fetal Neonatal Med. 2011;24(4):600-5.

280. Faye-Petersen OM. The placenta in preterm birth. J Clin Pathol. 2008;61(12):1261-75.

281. Romero R, Espinoza J, Goncalves LF, Kusanovic JP, Friel L, Hassan S. The role of inflammation and infection in preterm birth. Semin Reprod Med. 2007;25(1):21-39.

282. Kuban KC, O'Shea TM, Allred EN, Fichorova RN, Heeren T, Paneth N, et al. The breadth and type of systemic inflammation and the risk of adverse neurological outcomes in extremely low gestation newborns. Pediatr Neurol. 2015;52(1):42-8.

283. Dammann O, Allred EN, Fichorova RN, Kuban K, O'Shea TM, Leviton A, et al. Duration of Systemic Inflammation in the First Postnatal Month Among Infants Born Before the 28th
Week of Gestation. Inflammation. 2016;39(2):672-7.

284. Leviton A, Allred EN, Fichorova RN, Kuban KC, Michael O'Shea T, Dammann O, et al. Systemic inflammation on postnatal days 21 and 28 and indicators of brain dysfunction 2years later among children born before the 28th week of gestation. Early Hum Dev. 2016;93:25-32.

285. McAdams RM, Juul SE. The role of cytokines and inflammatory cells in perinatal brain injury. Neurol Res Int. 2012;2012:561494.

286. Adams Waldorf KM, McAdams RM. Influence of infection during pregnancy on fetal development. Reproduction. 2013;146(5):R151-62.

287. Haynes RL, Sleeper LA, Volpe JJ, Kinney HC. Neuropathologic studies of the encephalopathy of prematurity in the late preterm infant. Clin Perinatol. 2013;40(4):707-22.

288. Kinney HC. The encephalopathy of prematurity: one pediatric neuropathologist's perspective. Semin Pediatr Neurol. 2009;16(4):179-90.

289. Volpe J. Encephalopathy of prematurity includes neuronal abnormalities. Pediatrics. 2005;116(1):221 - 5 .

290. Volpe JJ. The encephalopathy of prematurity--brain injury and impaired brain development inextricably intertwined. Semin Pediatr Neurol. 2009;16(4):167-78.

291. Ball G, Pazderova L, Chew A, Tusor N, Merchant N, Arichi T, et al. Thalamocortical Connectivity Predicts Cognition in Children Born Preterm. Cereb Cortex. 2015.

292. Counsell SJ, Dyet LE, Larkman DJ, Nunes RG, Boardman JP, Allsop JM, et al. Thalamo-cortical connectivity in children born preterm mapped using 


\section{The Unifying Effects of Maternal-Placental-Fetal Axis Dysregulation on Neurodevelopment Following Infectious and Toxic In Utero Insults}

probabilistic magnetic $\begin{array}{r}\text { resonance } \\ \text { tractography. }\end{array}$
Neuroimage. 2007;34(3):896-904.

293. Counsell SJ, Edwards AD, Chew AT, Anjari M, Dyet LE, Srinivasan L, et al. Specific relations between neurodevelopmental abilities and white matter microstructure in children born preterm. Brain : a journal of neurology. 2008;131(Pt 12):3201-8.

294. Counsell SJ, Shen Y, Boardman JP, Larkman DJ, Kapellou O, Ward P, et al. Axial and radial diffusivity in preterm infants who have diffuse white matter changes on magnetic resonance imaging at term-equivalent age. Pediatrics. 2006;117(2):376-86.

295. Inder TE, Wells SJ, Mogridge NB, Spencer C, Volpe JJ. Defining the nature of the cerebral abnormalities in the premature infant: a qualitative magnetic resonance imaging study. $\mathrm{J}$ Pediatr. 2003;143(2):171-9.

296. Woodward LJ, Edgin JO, Thompson D, Inder TE. Object working memory deficits predicted by early brain injury and development in the preterm infant. Brain. 2005;128(Pt 11):2578-87.

297. Jaques SC, Kingsbury A, Henshcke P, Chomchai C, Clews S, Falconer J, et al. Cannabis, the pregnant woman and her child: weeding out the myths. J Perinatol. 2014;34(6):417-24.
298. Grewen K, Salzwedel AP, Gao W. Functional Connectivity Disruption in Neonates with Prenatal Marijuana Exposure. Front Hum Neurosci. 2015;9:601.

299. Salzwedel AP, Grewen KM, Vachet C, Gerig G, Lin W, Gao W. Prenatal drug exposure affects neonatal brain functional connectivity. J Neurosci. 2015;35(14):5860-9.

300. Goldschmidt L, Richardson GA, Larkby C, Day NL. Early marijuana initiation: The link between prenatal marijuana exposure, early childhood behavior, and negative adult roles. Neurotoxicol Teratol. 2016;58:40-5.

301. Richardson KA, Hester AK, McLemore GL. Prenatal cannabis exposure - The "first hit" to the endocannabinoid system. Neurotoxicol Teratol. 2016;58:5-14.

302. Sonon K, Richardson GA, Cornelius J, Kim KH, Day NL. Developmental pathways from prenatal marijuana exposure to Cannabis Use Disorder in young adulthood. Neurotoxicol Teratol. 2016;58:46-52.

303. Chang L, Oishi K, Skranes J, Buchthal S, Cunningham E, Yamakawa $\mathrm{R}$, et al. Sex-Specific Alterations of White Matter Developmental Trajectories in Infants With Prenatal Exposure to Methamphetamine and Tobacco. JAMA Psychiatry. 2016;73(12):1217-27. 